\title{
Circular Economy Performance Measurement in Manufacturing Firms: A Systematic Literature Review with Insights for Small and Medium Enterprises and New Adopters
}

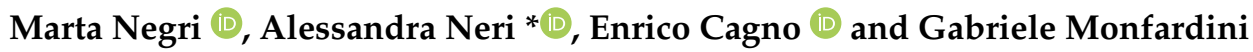

check for

updates

Citation: Negri, M.; Neri, A.; Cagno, E.; Monfardini, G. Circular Economy Performance Measurement in Manufacturing Firms: A Systematic Literature Review with Insights for Small and Medium Enterprises and New Adopters. Sustainability 2021, 13, 9049. https://doi.org/10.3390/ su13169049

Academic Editor: Ioannis Nikolaou

Received: 7 July 2021

Accepted: 9 August 2021

Published: 12 August 2021

Publisher's Note: MDPI stays neutral with regard to jurisdictional claims in published maps and institutional affiliations.

Copyright: (c) 2021 by the authors. Licensee MDPI, Basel, Switzerland. This article is an open access article distributed under the terms and conditions of the Creative Commons Attribution (CC BY) license (https:// creativecommons.org/licenses/by/ $4.0 /)$
Department of Management, Economics and Industrial Engineering, Politecnico di Milano, 20156 Milan, Italy; marta.negri@polimi.it (M.N.); enrico.cagno@polimi.it (E.C.); gabriele.monfardini@mail.polimi.it (G.M.)

* Correspondence: alessandra.neri@polimi.it

\begin{abstract}
The circular economy is a central and increasingly important topic within managerial and academic discourse. Although the circular economy could bring benefits to their performance, manufacturing firms still struggle with its adoption. As an effective adoption should pass for adequate performance measurement, the present study performs a systematic literature review to deepen the knowledge of circular economy performance-measurement systems for manufacturing firms, both from a general perspective and to provide specific insights for small-medium enterprises and new adopters. The results show the lack of an integrated, holistic, and scalable framework for measuring circular economy performance, and only a few and dispersed specific indications for smallmedium enterprises and new adopters. Shortcomings of the extant literature are identified in terms of integration of the circular economy's level, theoretical development and empirical application, characteristics of the indicators proposed, considerations of sustainability, holistic perspectives on industrial systems, and scalability to adapt to firms' different characteristics. The study paves the way for further research while offering theoretical and practical implications.
\end{abstract}

Keywords: circular economy; performance indicators; small and medium enterprises; new adopters; manufacturing sector; systematic literature review

\section{Introduction}

The concept of a circular economy (CE) emerged in the 1990s, as the link between environmental preservation and industry's economic performance [1]. Nonetheless, only recently has the CE paradigm gained adequate significance [2], as the manufacturing sector perceived the need to reduce resource depletion, minimize waste, and lower its environmental impact [3,4]. According to Kirchherr et al.'s definition [2], CE can be applied at three different levels, namely the micro (single firm, from a single product to the advertisement), the meso (industrial systems and networks), and the macro (society or Country) level, and it entails the inclusion of the waste hierarchy (prevention, reduce, reuse, recycle, recovery, disposal). Additionally, CE is strongly linked with sustainability, and it is necessary to properly understand their relationship for a complete overview of CE as a concept $[5,6]$.

Manufacturing firms can significantly benefit from the CE paradigm, both in terms of environmental preservation and economic gains [7,8]. Nonetheless, firms still struggle with the adoption of the CE paradigm and its related practices and interventions [9]. The measurement of performance is paramount to track progress and foster the implementation of the CE paradigm [10,11]. From this standpoint, the literature proposed several different frameworks and methodologies to measure CE-related performance [4]; the methods employed are rather varied, such that additional work to combine them has been called out for [12]. The extant efforts also differ in terms of context investigated, such as sector [13] or geographical area [14,15], or in terms of levels of application [16,17]. Although such 
diversity allows for a tailored performance measurement, it might (i) undermine interoperability; (ii) not be appropriate to support firms toward their incremental adoption of the CE paradigm; and (iii) restrict benchmarking activity [18]. From this perspective, it would be of great interest to synthesize and organize the ideas and contributions towards the measurement of CE-related performance in manufacturing firms [12], and, particularly, towards the features that an effective performance-measurement system should have [18]. The first question the present study aims at answering is:

RQ1. How can CE performance be measured in manufacturing firms?

The proper adoption of a specific performance-measurement system could nonetheless clash with some firms' characteristics. For example, the lack of resources and a blurred strategy might exert a negative influence on the development of a performance-measurement system [19]; resource and capability constraints, as well as the lack of operative instruments, could negatively impact the process of reporting [20]; besides limited resources, differences among firms depend also on strategy design and organizational setting [21], while the level of awareness results as fundamental for the diffusion of new concepts and paradigms within a firm $[22,23]$. The abovementioned characteristics distinguish firms to a different extent, but apply particularly to two types of firms: small-medium enterprises (SMEs) and the new adopters (NAs). SMEs refer to firms with less than 250 employees and an annual turnover not exceeding 50 million $€$ [24]. Despite their prominent role, in the European context, in terms of economic, social, and environmental impacts $[25,26]$, SMEs often lack appropriate know-how, resources, and support [27]. SMEs are usually resource-constrained, in terms of time, staff, and economic resources, compared to larger firms [26]. SMEs are also generally less prone than large enterprises (LEs) to undertake transformational changes [28] and appear limitedly conscious of their impact on the environment and society [29]. Their size could be, at first glance, considered a proxy of their competencies [30], although this might not always be the case [31]. CE adopters can be defined as firms born in a linear economy, making efforts to implement $\mathrm{CE}$ in their existing business models [32]. NAs can be defined as firms at the first stages of the circular transition $[33,34]$ and at the initial stage of the adoption process [35]. NAs can face specific problems in relation to aspects of strategy, organizational structure, and performance management [21]. They might require additional support during the adoption process, as they may not be able to develop the required know-how $[4,36]$. Despite the relevance of the $\mathrm{CE}$ in the current debate, still, a large share of firms can be considered NAs, as the adoption of the CE paradigm occurs slowly Table 1 distinguishes SMEs and NAs according to four characteristics that emerged as pivotal from the above discussion, namely resource constraints, awareness, competences, and maturity level. Each of these characteristics might apply in different ways and to different extents to SMEs and NAs. As it can be inferred from Table 1, a firm could be both an SME and an NA; nonetheless, also LEs can be included within NAs, while native firms, i.e., firms founded on CE principles, might include SMEs [32].

Table 1. Categorization of SMEs and NAs according to pivotal characteristics. The table categorizes SMEs and NAs according to four characteristics that emerged as pivotal from the literature, namely resource constraints, awareness, competences and maturity level. The indicates that the feature is recognized as a main characteristic for the specific types of firm; the indicates that the characteristic could or could not apply for the specific firms. Supporting references are provided.

\begin{tabular}{cccc}
\hline Characteristics & SMEs & NAs & Supporting References \\
\hline $\begin{array}{c}\text { Resources constraints. Availability of resources } \\
\text { as time, staff, and economic resources }\end{array}$ & $\diamond$ & $\odot 37,38]$ \\
\hline $\begin{array}{c}\text { Awareness. Awareness over a specific aspect of } \\
\text { interest and over the firm's impact on it }\end{array}$ & $\diamond$ & $\checkmark$ & {$[35,39-41]$} \\
\hline $\begin{array}{c}\text { Competence. Adequate competences to tackle } \\
\text { the specific aspect of interest }\end{array}$ & $\diamond$ & $\diamond$ & {$[30-32,35]$} \\
\hline $\begin{array}{c}\text { Maturity Level. Maturity level in terms of } \\
\text { transition towards the specific aspect of interest }\end{array}$ & $\diamond$ & {$[27,32,35]$} \\
\hline
\end{tabular}


Such a categorization is relevant for properly understanding the needs of the different types of firms, and, as for the measurement of performance, reasoning on their specific characteristics [42,43]. An effective performance-measurement system should indeed allow for both a general and a tailored application, having flexibility as one of its main features, so as to adapt to a firm's continuous and dynamic evolution [18]. Despite its relevance, such an approach is still missing in the extant literature [44,45]. Focusing on SMEs and NAs, some contributions attempted to study CE implementation in SMEs [5], but evidence is scant and there is no indication of such effort for NAs. On the other hand, methods not specifically addressing SMEs or NAs might result in being too burdensome or difficult to adopt [42]. From this stand point, considering how $\mathrm{CE}$ performance can be measured in manufacturing firms, it is pivotal to understand the implications of the different characteristics of SMEs and NAs on the development of effective performance-measurement systems. Thus, the second question this study aims to answer is:

RQ2. What are the related implications for SMEs and NAs?

Leveraging the above and considering the specific targets of synthetizing and organizing the previous knowledge, the present study conducts a systematic literature review to answer the two research questions. The present study will address the measurement of $\mathrm{CE}$ performance from the perspective of the characteristics that an effective performancemeasurement system should have, from a general viewpoint and particularly for being adequate and appropriate for application in SMEs and NAs.

The remainder of this paper is structured as follows. A detailed description of the systematic literature review methodology is provided by clearly outlining the followed steps (Section 2). After a descriptive analysis and evaluation of emerging themes (Section 3), the areas for which additional research is necessary are identified (Section 4). Finally (Section 5), pivotal implications of the study and possible further research are outlined.

\section{Methodology}

This study adopts a systematic literature review approach, identifying the contributions provided by the extant literature and possible emerging paths for future research [46]. The review is based on the procedure suggested by Howard et al. [47] and Tranfield and Denyer [48], adopting the following steps: (1) question formulation; (2) source identification; (3) study selection and evaluation; (4) analysis and synthesis; (5) reporting and using results.

\subsection{Question Formulation}

The objective of the review is to analyze in a comprehensive and informative manner the research questions illustrated in the previous section. According to the CIMO logic [49], we want to identify, considering manufacturing firms (context), frameworks and assessment methods (intervention) allowing the evaluation (mechanism) of CE-related performance (outcome).

\subsection{Source Identification}

A keywords-based search of the Scopus database was performed [50,51]. The search was performed on 4 May 2021 and updated on 2 July 2021. As per this study's goal, the keywords selected relate to performance measurement (indicator, KPI, performance, metric) or assessment procedure (assessment, measurement, analysis, evaluation), and terms related to the topic (circular economy, circularity). The selection of the keywords was based on previous publications, so as to ensure that the selected keywords were complete and appropriate for the scope of the present work: see [42,52] for keywords related to performance measurement and the assessment procedure; and [52-54] for keywords related to CE.

As for exclusion criteria, the analysis was limited to contributions published in English from the year 2000 onwards, while subject areas out of this study's interest, like medicine, the arts, and immunology were excluded. The procedure is reported in Table 2. A total of 
5820 contributions were retrieved. The set was purged, eliminating 66 contributions for which relevant and necessary information was not provided (no author/title information), obtaining a set of 5754 contributions considered for source selection.

Table 2. Query used for the source identification.

\begin{tabular}{cccc}
\hline & Criteria Selection for the Literature Review & \\
\hline Keywords & Language & Publication Year & $\begin{array}{c}\text { Subject Areas } \\
\text { Excluded }\end{array}$ \\
\hline TITLE-ABS-KEY & & \\
("circular economy" OR & & \\
circularity) & & & MEDI; PHYS; AGRI; \\
$\begin{array}{c}\text { AND TITLE-ABS-KEY } \\
\text { (indicator OR KPI OR }\end{array}$ & English & $>1999$ & EART; ARTS; NEUR; \\
performance OR metric & & PSYC; PHAR; IMMU; \\
OR assessment OR \\
measurement OR \\
analysis OR evaluation)
\end{tabular}

\subsection{Source Selection and Evaluation}

The selection of the contribution was performed based on the PRISMA methodology, which was deployed in the screening, eligibility, and inclusion phases. Each phase was conducted independently by each author and followed by a discussion within the research group, leading to a common decision on the inclusion or exclusion of a contribution, ensuring internal validity [46]. Additionally, no specific setting was addressed during the literature search and review other than the industrial context, strengthening the external validity [55]. The steps followed and assumptions made were explicit, so as to reduce bias. The PRISMA diagram, reported in Figure 1, shows the details for each phase.

The screening of the contributions was performed in two steps [56]. The first step employed a "title analysis". For the analysis, a manual coding was performed, wherein suggestions were made regarding the exclusion of contributions not considered relevant for the present work, or addressing a broader perspective on $\mathrm{CE}$, such as the region or country level. As a result of the title analysis, 5573 contributions were excluded, while 181 contributions were considered eligible for an abstract analysis. The second step consisted of this "abstract analysis"; here, 87 contributions were excluded and 94 were identified as suitable for undergoing the eligibility phase. The evaluation of the contributions' eligibility was based on a "full-text analysis". From this, 20 contributions were discharged, mainly because they were not proposing indicators for measuring CE or had a high-level scope. Finally, 74 contributions were deemed as relevant for our analysis and thus included in the final set. 


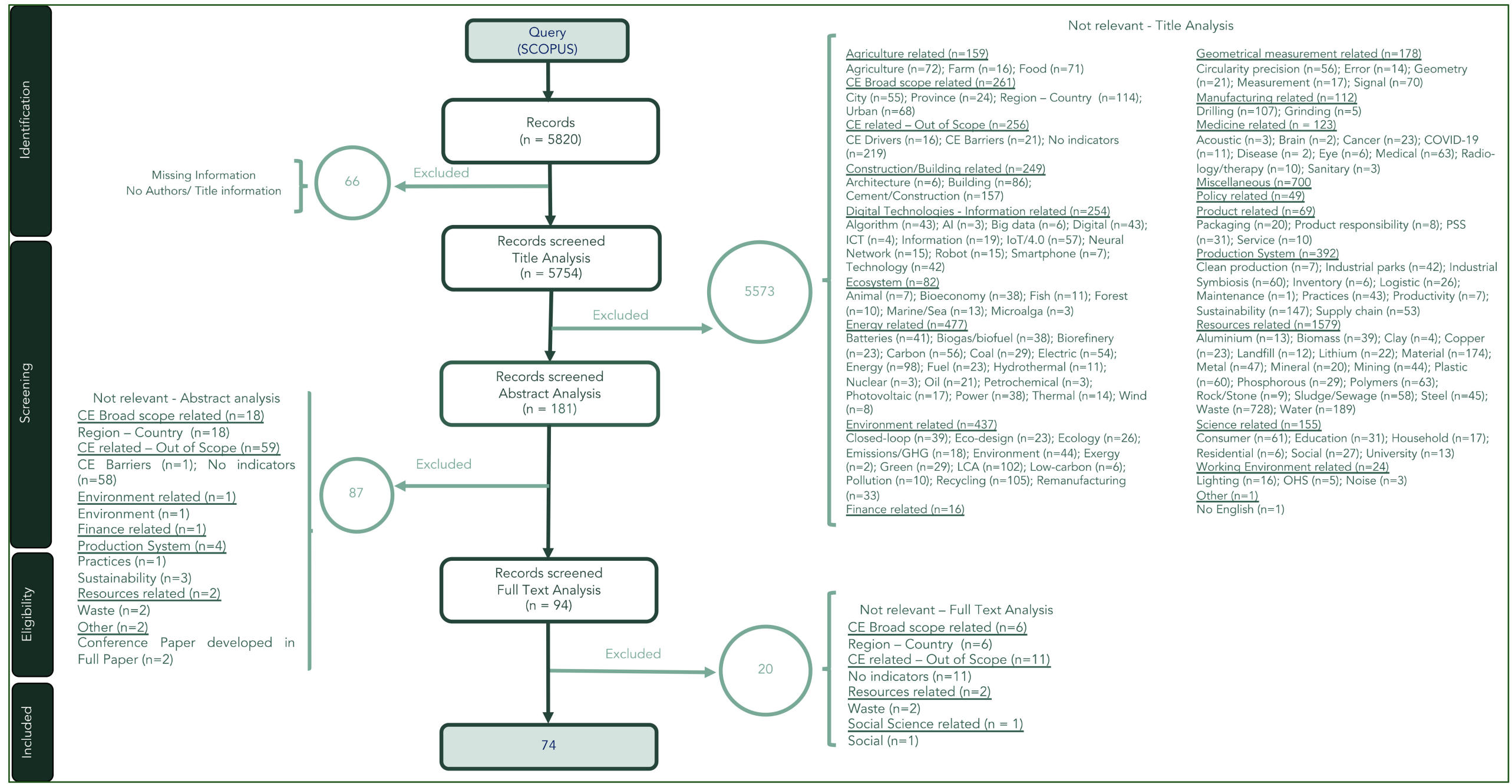

Figure 1. Details of the PRISMA procedure's phases. 
For the evaluation phase, the retrieved contributions were classified according to the selected critical dimensions of analysis, appropriate to the scope of the review. A content analysis for a qualitative material evaluation was performed [57]. The contributions were divided into literature reviews and original studies. As for literature reviews, the following were highlighted: general information (authors, date, journal) and characteristics of the review (focus; timespan; database; number of papers included). The axes of analysis for literature reviews were selected so to better understand the focus of the selected contributions and identify areas that still need to be addressed with regards to the aim of the present work [43]. concerning original studies, the following were pinpointed: general information (authors, date, journal); theoretical development (context of development; methodology); indicators (number; categorization; sustainability pillars; prioritization; index); empirical application (context of application; methodology; sample/set). the axes of analysis for original studies were selected to (i) characterize the performance-measurement systems according to features that emerged as interesting from the literature [43,58]; (ii) understand the context of development and application of the frameworks $[59,60]$.

The screening of the contributions and the content analysis were performed independently by three researchers (three of the four authors of the present paper). At every step, individual results were discussed, and a common result was defined and agreed upon. The results of the evaluation phase are presented and commented on in the next section.

\subsection{Data Analysis}

The data analysis was performed capturing relevant information through a critical investigation of the retrieved contributions [61], with a twofold perspective: (i) a descriptive evaluation, identifying quantitative trends, and (ii) a review of content in terms of emerging themes for the qualitative evaluation of research outcomes, identifying areas for which additional research is necessary.

\section{Findings: Descriptive Evaluation and Emerging Themes}

The section presents a descriptive evaluation and a discussion of emerging themes. The argument is divided between literature reviews and original research, and organized according to the axes of analysis introduced in Section 2.3.

\subsection{Literature Reviews}

The 13 retrieved reviews are recent and published after the year 2017. Most of them $(n=8)$ are published in the Journal of Cleaner Production; the others on Sustainability (Switzerland) $(n=2)$, Sustainable Production and Consumption $(n=2)$, and Resources, Conservation and Recycling $(n=1)$; therefore, the topic is addressed predominantly by journals combining environmental and managerial subject areas. Only one review explores methodologies the others analyze assessment frameworks for the micro level, either individually $(n=7)$, or combined with the meso and macro levels $(n=5)$.

Generally speaking, the literature reviews do not explicitly distinguish among the resource, material, product or firm levels of investigation [62]. The contributions still appear focused on the process or product level, and the possible actions integrated into industrial operations that can be undertaken at an industrial-plant level $[63,64]$ are not considered. Such a perspective could limit the potential of interventions, as many practices for enhanced CE go beyond the boundaries of production processes [5]. Additionally, the literature reviews address the measurement of performance from a general perspective. Only Lindgreen et al. [51] provide insights for SMEs, while no implications for NAs were investigated. Considering our research questions, a further step in the current literature appears necessary, focusing attention on the measurement of CE performance in manufacturing firms, with a focus on specific implications for SMEs and NAs.

The overall evaluation of the reviewed Literature Reviews s reported in Table 3. 
Table 3. Source Evaluation-Literature Reviews. The table reports general information of the considered literature reviews and provide insights on the characteristics of the review in terms of years, database and number of contributions considered, the circular economy level addressed, and the specific focus on SMEs and NAs.

\begin{tabular}{|c|c|c|c|c|c|c|}
\hline Ref. & Journal & $\begin{array}{c}\text { Years } \\
\text { Considered }\end{array}$ & $\begin{array}{c}\text { Databases } \\
\text { Considered }\end{array}$ & $\begin{array}{c}\text { Num. of } \\
\text { Contributions }\end{array}$ & $\begin{array}{c}\text { Level } \\
\text { Considered }\end{array}$ & $\begin{array}{c}\text { Focus on } \\
\text { SMEs/NAs }\end{array}$ \\
\hline$[65]$ & $\begin{array}{l}\text { Sustain. Prod. } \\
\text { Consum }\end{array}$ & $2013-2020$ & Scopus & 58 & micro; nano. & no \\
\hline [58] & J. Clean. Prod & 2000-2019 & Scopus, WoS & 61 & $\begin{array}{l}\text { micro; meso; } \\
\text { macro }\end{array}$ & no \\
\hline$[45]$ & $\begin{array}{l}\text { Sustain. Prod. } \\
\text { Consum }\end{array}$ & 2010-2019 & $\begin{array}{c}\text { Scopus, Google } \\
\text { Scholar }\end{array}$ & 135 & $\begin{array}{l}\text { micro; meso; } \\
\text { macro }\end{array}$ & no \\
\hline$[66]$ & Sustainability & 2009-2019 & $\begin{array}{c}\text { Springer; } \\
\text { Scopus; MDPI, } \\
\text { Whiley }\end{array}$ & 60 & $\begin{array}{l}\text { micro; meso; } \\
\text { macro }\end{array}$ & no \\
\hline$[67]$ & J. Clean. Prod & 2007-2015 & Scopus, WoS & 107 & micro & no \\
\hline$[51]$ & Sustainability & 2007-2019 & Scopus & 74 & $\begin{array}{l}\text { micro (firm; } \\
\text { product) }\end{array}$ & $\begin{array}{l}\text { insights for } \\
\text { SMEs }\end{array}$ \\
\hline$[44]$ & J. Clean. Prod & 2006-2019 & Scopus, WoS & 31 & micro & no \\
\hline$[68]$ & $\begin{array}{c}\text { Resour. } \\
\text { Conserv. Recycl }\end{array}$ & 2008-2018 & WoS & 72 & $\begin{array}{l}\text { micro; meso; } \\
\text { macro }\end{array}$ & no \\
\hline$[62]$ & J. Clean. Prod & n.a. & $\begin{array}{l}\text { Scopus, Web of } \\
\text { Science }\end{array}$ & 52 & $\begin{array}{c}\text { micro; } \\
\text { manufacturing }\end{array}$ & no \\
\hline$[34]$ & J. Clean. Prod & 2010-2018 & $\begin{array}{c}\text { Academic; } \\
\text { Non-academic }\end{array}$ & 49 & micro & no \\
\hline [69] & J. Clean. Prod & 2009-2018 & Scopus & 45 & methodology & no \\
\hline$[1]$ & J. Clean. Prod & 2004-2017 & Scopus & 601 & $\begin{array}{l}\text { micro; meso; } \\
\text { macro }\end{array}$ & no \\
\hline$[70]$ & J. Clean. Prod & 2003-2017 & $\begin{array}{l}\text { Scopus, Google } \\
\text { Scholar }\end{array}$ & 41 & $\begin{array}{l}\text { micro (reuse; } \\
\text { recycle) }\end{array}$ & no \\
\hline
\end{tabular}

\subsection{Original Studies}

\subsubsection{General Information}

The temporal distribution of original studies (Figure 2) allows identifying two agglomerations. The first $(n=13)$ consists of contributions published before 2015, and it is related to the Chinese context, due to China's early focus on CE [71]. The second $(n=48)$ starts from the year 2015 and mirrors the increasing interest of Europe [72].

The reviewed contributions were published in both peer-reviewed journals $(n=48)$ and conference proceedings $(n=13)$. Focusing on the former set, the most represented journals are Journal of Cleaner Production $(n=14)$, Resources, Conservation and Recycling $(n=6)$ and Sustainability (Switzerland) $(n=5)$. Considering the subject area(s) of these journals (Figure 3), the topic is mainly considered from an environment and management related perspectives $(n=25)$. 


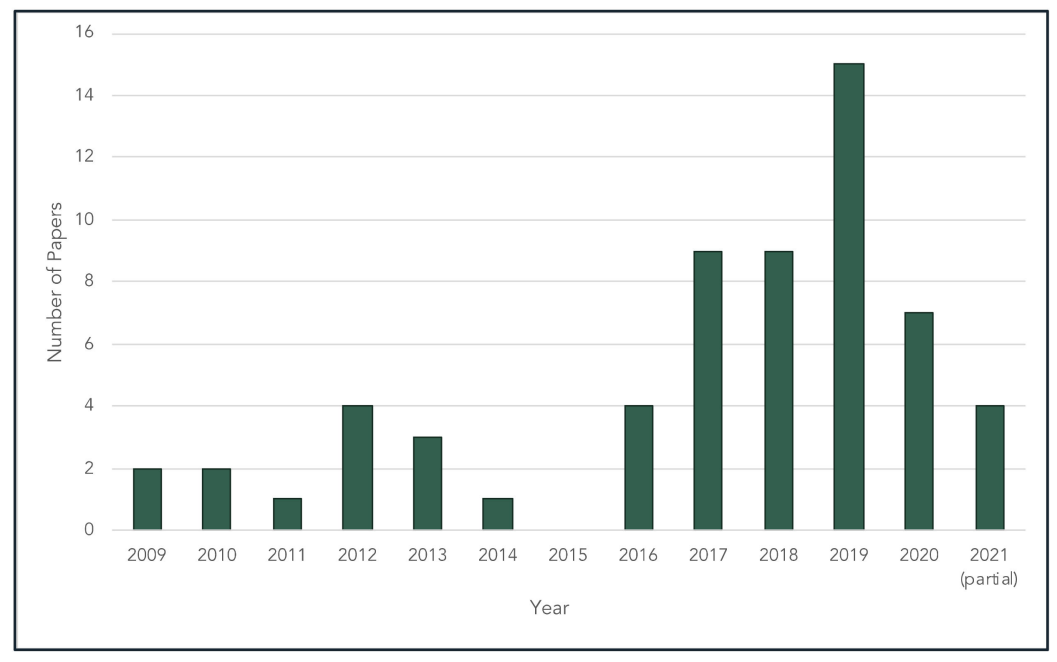

Figure 2. Original studies by year of publication.

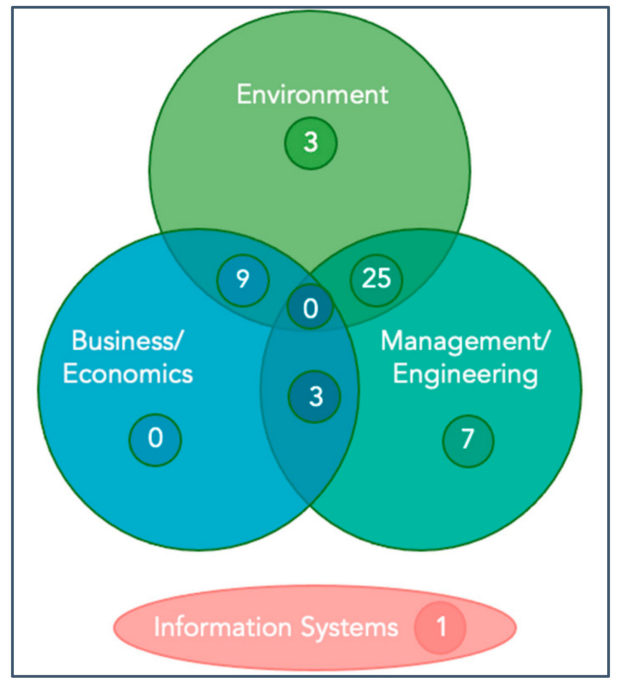

Figure 3. Original studies by area of journal.

\subsubsection{Circular Economy Level}

Despite all the reviewed contributions are focusing on issues of interest to the industrial decision-maker (IDM), they take different perspectives. The majority address frameworks at the single-product $(n=21)$ or the materials-and-resources level $(n=6)$, some consider the firm level $(n=19)$, others consider a system perspective $(n=8)$, while only a few studies $(n=6)$ analyze different levels simultaneously.

Micro Level. At the micro level, the largest share of the reviewed contributions focuses on a resource, material, or product level. Several methodologies for measuring the CE performance of products are proposed, and a common approach is not yet established. Besides proposing different approaches, the reviewed contributions also present diverse foci. For example, Di Maio et al. [73] and Linder et al. [74] developed indicators based on product economic and market value; Figge et al. [75] proposed longevity indicators to consider the closed loops of products; others focus only on one phase of the life cycle, such as reparability [76], recycling [77], or end-of-life [78,79].

Within the micro level, models addressing a product's circularity are largely diffused, but might present drawbacks for the measurement of the overall firm performance on $\mathrm{CE}$, as it is not clear how to scale them up at the firm level. From this standing, their use for supporting the enhancement of firms' CE performance might be limited. A possible solution could be applying product-level indicators to all products manufactured by 
a firm, assigning weights based on quantities [80]. As a drawback, such a procedure would require a considerable amount of information for firms producing several different products, as it typically happens in manufacturing firms; besides, the procedure would be time-consuming, requiring high levels of awareness and competency [51]. Bearing that in mind, such a solution for the evaluation of a firm's performance would not be suitable for resource-constrained firms or for firms at the beginning of their CE transition $[19,20]$. It would be too burdensome, with the possible pitfall of discouraging firms or not providing proper support during their transition. Moreover, the scale-up process might not include plant-level practices [63], which represents a further limitation.

The reviewed contributions also propose methods to gauge the CE performance of the entire firm. For example, Koksharov et al. [81] propose the use of indicators' values trends, over time, as a proxy of circularity development; Garza-Reyes et al. [4] assess firm's circularity with a qualitative questionnaire based on the practices implemented; Rincón-Moreno et al. [82] adapted the indicators, already present at the macro level, at the micro level, also leveraging interviews with IDMs; Rossi et al. [13] link indicators with levels of applicability and usefulness in reaching desired performance, guiding firms along the implementation of a measurement system, and facilitating the CE transition. A limited number of contributions focusing on a firm's level address specific firms' sizes. Four contributions focus on LEs; for example, Rossi et al. [13] state that frameworks should employ an industrial-systems perspective and include multi-dimensional indicators; Yadav et al. [15] propose a framework that includes advanced indicators, such as managerial, organizational and policy indicators. Three contributions focus on SMEs, among them Aravossis et al. [83] underline the need for tailoring tools to the requirements of SMEs in terms of efficiency; Garza-Reyes et al. [4] propose a toolkit for SMEs with nine progressive levels of circularity. The literature stressed how the systems developed for LEs might not be suitable for SMEs [18,20], as LEs are supposed to have more resources available. Nonetheless, the literature also showed that LEs do not necessarily imply implementing more advanced practices and tools [31].

Integration of Levels. Competitiveness is increasingly played among industrial systems-as supply chains, industrial parks or industrial districts $[18,84]$, rather than single firms $[85,86]$. Systems are pivotal for enhancing CE [2], so that a single firm's performance should be considered within the broader system in which it operates $[4,43]$. In the reviewed contributions, the micro and meso levels are separated, without an integrated micro-meso perspective. Mostly, the focus is generically only on meso level [87,88] supply networks [89], supply chains [90,91], and industrial parks [92]. Only Parchomenko et al. [93] consider both the micro and meso levels, but include the macro one, too. An integrated framework for the evaluation of performance that considers the micro level while also providing insights for the meso level would be of particular interest $[6,45,90]$, but it has not been properly addressed thus far. Such a framework would help firms appropriately allocating their resources to prioritize those systems addressing performance on two levels, and thus is expected to outperform the single-perspective solutions. Such a characteristic would be of great support for resource-constrained firms [4], as it would allow having a single and straightforward system, rather than several with excessively detailed information. At the same time, it could also be of relevance for firms with a low level of competence and maturity, as the system would allow the focus on those interventions and actions able to foster the enhancement of their transitions from a multi-level perspective, eventually maximizing outcomes. The overall evaluation of the reviewed original studies, with respect to the circular-economy level considered, is reported in Table 4. 
Table 4. Source Evaluation-Original Studies (CE Level and Theoretical Development). The table reports general information of the considered contributions and provides insights on: the circular economy level addressed; the theoretical development of the proposed framework in terms of context and methodology (AHP: analytic hierarchy process; BSC: balanced scorecard; CBA: cost-benefit analysis; EDIT: eco-innovation development and implementation tool; EF: ecological footprint; ETV: environmental technology verification; GMA: general morphological analysis; LCA: life-cycle assessment; LR: literature review; MCA: multiple correspondence analysis; MF: material flow; V: value-based; WIO: waste input-output; TOPSIS: technique for order preference by similarity to ideal solution).

\begin{tabular}{|c|c|c|c|}
\hline \multirow[b]{2}{*}{ Ref. } & \multirow{2}{*}{$\begin{array}{c}\text { CE Level } \\
\text { Level }\end{array}$} & \multicolumn{2}{|c|}{ Theoretical Development } \\
\hline & & $\begin{array}{l}\text { Context of Development } \\
\text { (Sector; Size; Area; Process) }\end{array}$ & Methodology \\
\hline$[94]$ & micro & - & $\begin{array}{c}\text { LR; experts; GMA; AHP; } \\
\text { TOPSIS }\end{array}$ \\
\hline [95] & firm & - & LR \\
\hline [17] & material & - & LR \\
\hline$[82]$ & firm & - & LR \\
\hline [96] & product & - & LR \\
\hline [97] & product & - & LR; LCA \\
\hline$[98]$ & product & plastic & $\begin{array}{l}\text { LR; experts' opinions; case } \\
\text { studies }\end{array}$ \\
\hline [99] & product & manufacturing & LR; experts' opinions \\
\hline$[13]$ & firm & electronic, textile, plastic & $\begin{array}{l}\text { interviews; surveys; Focus } \\
\text { group }\end{array}$ \\
\hline$[14]$ & firm & Europe & LR; experts' opinions \\
\hline [15] & firm & emerging economies & $\begin{array}{l}\text { LR; experts' opinions; } \\
\text { Interviews; Survey }\end{array}$ \\
\hline [100] & product & pharmaceutical & LR; MF \\
\hline [79] & product & end of life & LR \\
\hline [83] & firm-SME & SMEs & LR; LCA; MF \\
\hline [101] & product & - & LR \\
\hline [102] & firm & pulp and paper & LR \\
\hline$[4]$ & firm-SMEs & manufacturing; SMEs & LR; MF \\
\hline$[78]$ & product & tires production; end of life & LR \\
\hline [103] & micro & & LR; LCA \\
\hline$[54]$ & firm & LEs & LR; MCA \\
\hline [104] & product & plastic (waste) & LR; experts' opinions \\
\hline [81] & firm & - & LR; LCA \\
\hline$[16]$ & micro \& macro & - & LR; experts' opinions \\
\hline [105] & product & - & CBA; LCA \\
\hline [93] & micro, meso, macro & - & LR \\
\hline [106] & firm & food & LR; EDIT; experts' opinions \\
\hline [89] & supply network & - & LR \\
\hline [107] & product & food & LR \\
\hline [75] & resource & - & LR; LCA \\
\hline$[77]$ & product & recycling & LR; MF \\
\hline [90] & supply chain & - & LCA \\
\hline [91] & supply chain & - & $\begin{array}{l}\text { LR; companies' reports; } \\
\text { interviews }\end{array}$ \\
\hline [108] & product & - & MF; LCA; British standard \\
\hline [109] & micro & & $\mathrm{LR} ; \mathrm{MF}$ \\
\hline [110] & product & & LR; LCA; MF; ETV \\
\hline [111] & product & - & LCA \\
\hline [112] & firm & manufacturing & LR \\
\hline [88] & meso & - & LR; survey \\
\hline
\end{tabular}


Table 4. Cont.

\begin{tabular}{|c|c|c|c|}
\hline \multirow[b]{2}{*}{ Ref. } & \multirow{2}{*}{$\begin{array}{c}\text { CE Level } \\
\text { Level }\end{array}$} & \multicolumn{2}{|c|}{ Theoretical Development } \\
\hline & & $\begin{array}{c}\text { Context of Development } \\
\text { (Sector; Size; Area; Process) }\end{array}$ & Methodology \\
\hline$[53]$ & product & manufacturing & LR; V \\
\hline [73] & resource & - & LR \\
\hline [113] & product & - & $\mathrm{V}$ \\
\hline$[74]$ & product & - & LR \\
\hline [114] & product & - & LR; BSC \\
\hline$[31]$ & firm & biotech and pharmaceutical & LR \\
\hline$[76]$ & product & repairing & LR; experts' opinions \\
\hline [115] & material & - & LR; LCA; simulation \\
\hline [116] & product & vehicles end of life & $\mathrm{MF} ; \mathrm{V}$ \\
\hline [117] & firm & metallurgy & $\begin{array}{l}\text { LR; companies' reports; } \\
\text { survey }\end{array}$ \\
\hline [118] & material & - & LR \\
\hline [119] & firm & manufacturing & LR \\
\hline [87] & meso & - & LR; LCA \\
\hline [120] & firm & manufacturing & $\mathrm{LR} ; \mathrm{MF}$ \\
\hline [121] & meso and macro & - & LR \\
\hline [122] & firm & - & LR \\
\hline [123] & meso & - & LR \\
\hline [124] & firm & chemical & LR; WIO \\
\hline [92] & industrial parks & - & Chinese regulations \\
\hline [125] & firm & manufacturing & LR; Chinese regulations \\
\hline [126] & firm & manufacturing & LR \\
\hline [127] & supply chain & - & LR; MF; EF \\
\hline [128] & firm & energy-intensive sectors & LR \\
\hline
\end{tabular}

\subsubsection{Theoretical Development: Methods and Contexts}

Following [129,130], contributions are grouped into theoretical (only introducing a new theoretical framework) and theoretical-empirical (theoretical framework coupled with an empirical application). Some of the reviewed contributions $(n=20)$ are only theoretical, while most of them $(n=41)$ are theoretical-empirical. The methodology employed for their theoretical development is, for almost the totality of cases $(n=54)$, a literature review, sometimes complemented by other considerations based, for example, on lifecycle assessment or material flow analysis. The previous literature is generally considered a solid base and a good proxy for the relevance of the specific aspects tackled [131,132]. Nonetheless, the literature alone is not sufficient, and should be integrated with other development backgrounds, such as IDMs and experts [42,43]. Only a few contributions included a panel of experts [14], case studies [98], surveys [88], or a mix of the above [15] in their theoretical development. Only a multi-perspectives approach could avoid bias due to the consideration of only a specific viewpoint [31]. The involvement of IDMs is fundamental for tailoring a general system to the specific characteristics of the reference firm.

As for the theoretical development, several contributions focus on a single context. In terms of sector, studies address manufacturing in general $[99,120]$, but many are tailored to specific sectors such as pulp and paper [102], tire production [78,95], plastics [104], or chemicals [124]. Concerning geographical areas, some studies focus on Europe [14] or emerging economies [15]. In both cases, the development of the model could be biased by the selected contextual factors, so the applicability in different contexts should be further investigated [133], possibly leading to the development of indicators suitable for various contexts [42,53]. As for size, three studies address SMEs [4,83], one LEs [54], while the remaining do not focus their theoretical development on one or more specific firms' dimensions. If this, on the one hand, allows for a general system to be proposed, on the other hand, it might then represent a drawback to the adoption of the proposed frameworks by firms of different sizes, and, particularly, by SMEs. SMEs indeed might need a more 
straightforward tool [42,133], specifically, as they potentially have limited resources and capability to collect the large amount of data required for some of the frameworks proposed in the literature [20]. The overall evaluation of the reviewed original studies as for the theoretical development is reported in Table 4.

\subsubsection{Circular Economy Performance Indicators}

Number of indicators. The studies show a high variance in terms of the number of indicators proposed, with a range from 1 to 189 (Figure 4), for a total of 1066 performance indicators. Almost half of the studies $(n=26)$ propose less than 10 indicators, while very few more than 35 indicators $(n=3)$. The average number of indicators was 17.48; the average is far from the median of 13 and a high standard deviation of 26 indicators is observed. As the average appears biased by the contribution proposing 189 indicators [91], the exclusion of this study leads to an average of 14.62 indicators, with 12.5 indicators as median and 13.54 indicators as standard deviation.

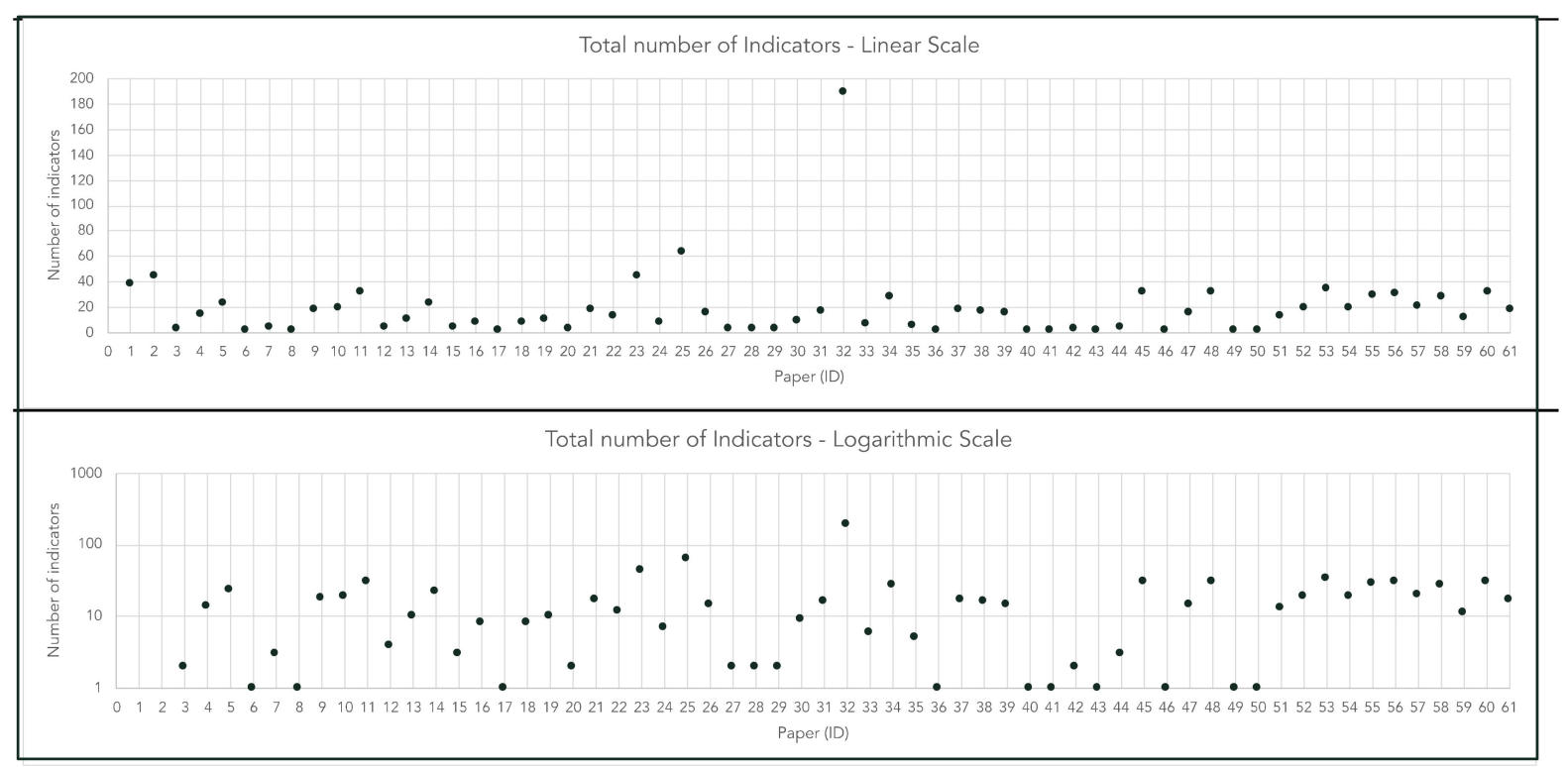

Figure 4. Original studies by the number of indicators.

The variety in the number of the proposed indicators is significant, with the risk of confusing firms and slow down CE adoption [82]. CE is a complex topic, requiring several indicators to be properly addressed [13]. A framework for measuring CE performance should be thus characterized by an appropriate breadth and depth. Such a level of detail would require a high number of indicators [134], but it is advisable to use a limited set of indicators, keeping them informative and not confusing $[42,135,136]$. An accepted threshold number of indicators has not yet been established in the literature, and suggestions range between 5 and 60 indicators [137,138], while empirical applications suggest a range from 20 to 70 , depending on the context $[133,139]$. As some of the reviewed contributions can be placed in this range $[31,117,124]$, the literature is still missing a proposal for adapting a system based on the specific context under evaluation.

Previous studies suggest that a framework for measuring performance should be manageable and easy to handle, while also guiding firms towards enhanced performance and a more structured approach towards CE [42]. Firms with low awareness, resources and competencies may require few indicators, providing an effective and efficient measurement of performance. With an increasing availability of resources and maturity, the system may be expanded to include more indicators [4]. Ideally, the frameworks should be scalable to support a firm at all the stages of resources, awareness, competence levels during their CE transition $[43,134]$. 
Categorization of indicators. Given the complex nature of the concept, systems for the measurement of CE-related performance should be addressed from a multi-dimensional perspective [82]. In general terms, authors provide frameworks of indicators that include economic- and productivity-related aspects [31,88,91], environmental aspects $[117,121,124]$, and social and institutional aspects [91,123].

Almost half of the studies still do not propose a categorization of their indicators. The most common categorization is based on the traditional or slightly modified triple bottom line. All the remaining studies propose their categorizations, leading to a high level of heterogeneity and unclear indications for IDMs. Categories should be designed to allow ease of understanding, above all for those firms with limited competences. Nonetheless, it could be difficult to strictly assign a performance indicator to a single and unique category [42,132]. In this way, indicators able to cover multiple aspects (i.e., be part of multiple categories) could provide better indications to IDMs [43]. Focusing on those indicators able to maximize the content of information could be a great help for firms characterized by limited resources or at the beginning of their circular transitions [42]. Indeed, such a system would allow focusing on the most impactful indicators, obtaining the greatest amount of information with a minimum number of indicators.

Integration with the sustainability pillars. When the association was possible and not doubtful (734 out of 1066), we categorized indicators based on the three pillars of sustainability (Figure 5).

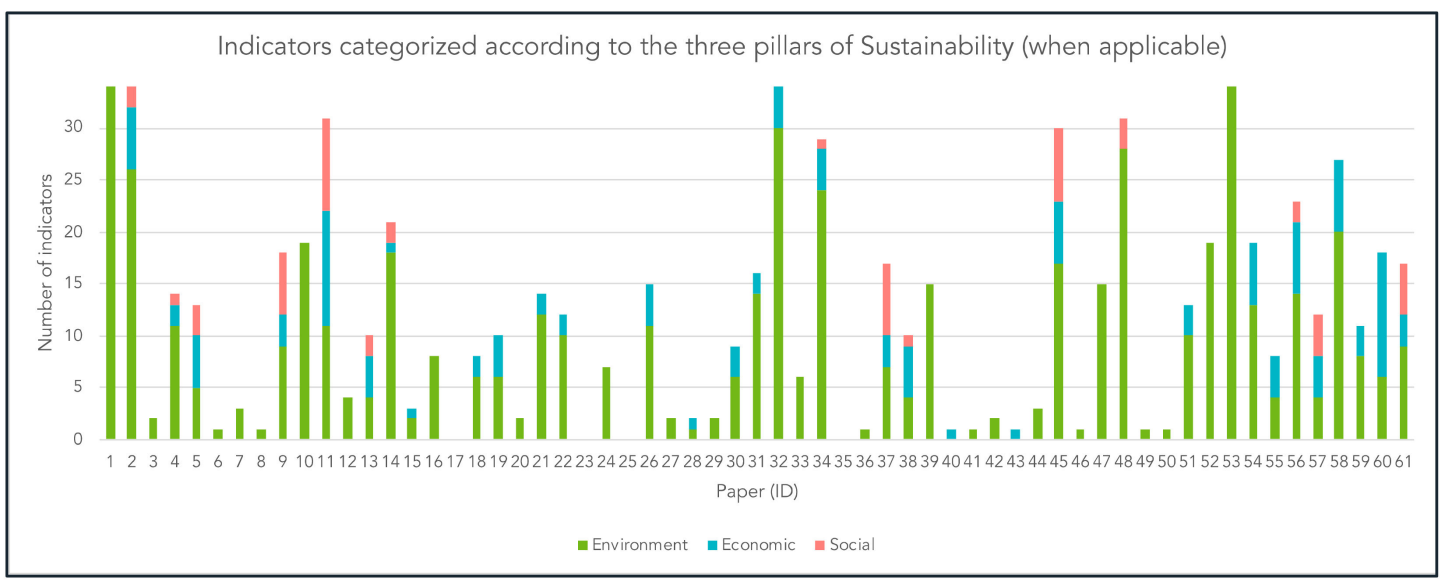

Figure 5. Original studies by the number of indicators categorized according to the three Sustainability pillars.

The need to provide an integrated view on CE and sustainability is largely stressed [6,62]. The link between the two concepts is considered in many definitions of CE [140], such that $\mathrm{CE}$ indicators should encompass the three pillars of sustainability [68]. In the reviewed contributions, an imbalance appears towards the environmental pillar, accounting for about $73 \%$ of the indicators, while the economic and social ones account for $18 \%$ and $9 \%$, respectively. The finding is strongly supported by previous literature [44], urging the inclusion of more economic- and, above all, social-related indicators [102,105].

Environmental indicators often show a life-cycle perspective [96], including cumulative energy demand, global-warming potential, and water-stress index [98]. Some authors focus on the dimension of material utilization, as CE promises to minimize resource consumption: Rossi et al. [13] list reduction of raw material, renewability, recyclability, reduction of toxic substances, reuse, remanufacturing, refurbishment, product longevity, stakeholder structure, and diversity; Sánchez-Ortiz et al. [14] develop an environment-focused system, including indicators ranging from material consumption, toxicity of materials, generation of waste, and recycling rate and quality. Another main focus provided by the reviewed contributions is end-of-life solutions, like recycling, somewhat failing to address the other 'Rs' and the waste hierarchy [77], or clearly distinguish between strategies aimed at managing the end-of-life and the lifespan of products [17]. Since retaining the value 
of products and materials is one of the key features of $\mathrm{CE}$, it makes sense to measure this aspect with particular care. However, $\mathrm{CE}$ is a more complex and multi-faceted paradigm, and complete frameworks of indicators should also include other environmental and social indicators. CE and social aspects are related in many ways, as concerns labor practices and decent work, human rights, society, and product responsibility. As employment, health and safety, and participation are most commonly included in CE [13,66], an additional step should be taken to include aspects other than internal ones [62]. Padilla-Rivera et al. [141] focus their attention on social indicators for $\mathrm{CE}$, providing a valuable perspective that nonetheless needs integration with environmental and economic aspects.

To have an integrated model, able to reconcile sustainability and CE and their intersection, would be of great relevance [142,143]. Particularly, firms with limited resources or competences could benefit from the availability of an integrated performance-measurement systems able to include aspects related to two different yet interrelated concepts [13,74]. Such a system would indeed allow for a more straightforward measurement of performance, helping firms better organize resources towards those efforts indicating positive outcomes on both the concepts.

Prioritization of Indicators. A limited set of contributions $(n=4)$ provides a prioritization of indicators. The prioritization of indicators could be very useful for firms to identify and focus on those considered relevant [144]. Indeed, such prioritization could allow firms to begin their performance measurement with a limited number of indicators, only subsequently moving to a larger set [145]. Given the difficulty in measuring and improving all indicators at once, prioritization aims to identify the most urgent, providing beneficial insights to IDMs. The prioritization proposed by the reviewed studies follows different approaches: Cristóbal et al. [107] prioritize indicators according to the waste hierarchy; Wenbo [92] prioritizes indicators based on the 5R principle (rethinking, reduce, reuse, recycle, repair); Cayzer et al. [53] prioritize according to the relative importance of indicators, following IDMs' perspectives; Yadav et al. [15] prioritize and divide indicators into categories based on empirical evidence from a case study. Intuitively, the feature would be extremely useful for firms with limited resources and competences, or at the initial stages of their circular transition, as it would allow them to identify the key indicators to focus on [19].

A relevant aspect of prioritization concerns who performs it [18]. A proper prioritization should consider different perspectives, such as those of IDMs, experts, external stakeholders, or academics [146]. This would help overcome the subjectivity of a single perspective [83], resulting in, nonetheless, more complexity [43]. Particularly, the identification of the right IDMs can be rather challenging in firms with little coordination among different departments [19] or with problems assigning decisional power to project champions [147], given their size or immaturity.

Development of an index. About half of the studies $(n=26)$ consider the development of an index, i.e., a combination of indicators providing a snapshot of a given performance area, although the trend decreases from the year 2016 onward [122,126]. The use of an index presents several benefits: it is easy to understand, communicate, and benchmark efforts towards CE [107]. Among the most common indexes, it is possible to cite the Circular Economy Indicator Prototype [53], the Circular Economy Toolkit [148]; the Material Circularity Indicator [80]. All three are nonetheless related to the product level and focus mainly on environmental aspects, although business opportunities are described by the Circular Economy Toolkit. Albeit straightforward in their use, indexes present drawbacks in their application, as they neither distinguish between different loops (e.g., reuse, refurbish, recycle) nor provide guidance for circular product development [34]. Garza-Reyes et al. [4] tried to shift the evaluation of circularity from the product to the firm level, according to the CE practices implemented, providing practical suggestions to IDMs mainly from a qualitative perspective.

One main issue related to the development of an index lays in the possible subjectivity of evaluation [83] of how different indicators should be weighted in their contributions 
to the overall index [91]. Some studies apply the analytic hierarchy process $[87,124]$, use fuzzy methods [125,126], or a combination of them [123]. Others propose the use of the multi-criteria evaluation method $[96,105]$. The majority of the studies, nonetheless, develop their index according to a ratio of quantities, considering the quantity of a particular material used over the total weight of a product [97] or the correspondent economic value [99]. These approaches can present drawbacks, as the development of the index is largely dependent on the perspective of whoever performs the selection [92,147], leading to possible inconsistency and subjectivity $[149,150]$. A way to overcome this impediment would be to include more than one perspective, such as those of internal and external stakeholders, experts, and academics [146]. For example, Cayzer et al. [53] rely on insights from the literature and IDMs, while Cristóbal et al. [107] test weighting factors retrieved from both grey and academic literature.

Indexes could represent valid help for firms with limited resources or a low level of maturity. Indeed, indexes allow quick assess of performance and provide benchmarks between different firms or different years, which also allows the tracking of progress. Nonetheless, a single index could entail a narrow scope [68], unable to consider all the multi-faced aspects of CE $[16,53]$. A proper starting point could entail two or three main indexes [151,152], with indications and guidelines towards enhanced CE and an integrated measurement of the related performance.

The overall evaluation of the reviewed original studies, as regards circular economy performance indicators, is reported in Table 5.

Table 5. Source Evaluation-Original studies (circular economy performance indicators). The table reports general information of the considered contributions and provides insights on the circular economy performance indicators in terms of number ( ${ }^{\circ}$ based on practices; retrieve from previous contributions), categorization (TBL: triple bottom line; BSC: balanced scorecard; SCOR: supply chain operations reference), sustainability pillars considered, prioritization and index

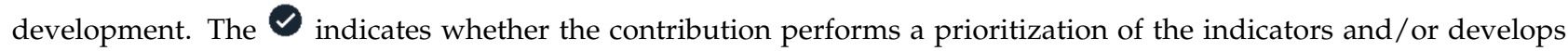
an index.

\begin{tabular}{|c|c|c|c|c|c|c|c|}
\hline \multirow{3}{*}{ Ref. } & \multicolumn{7}{|c|}{ Circular Economy Performance Indicators } \\
\hline & \multirow{2}{*}{ Num. } & \multirow{2}{*}{ Categorization } & \multicolumn{3}{|c|}{ TBL Pillars } & \multirow{2}{*}{ Prioritization } & \multirow{2}{*}{ Index } \\
\hline & & & Eco & Env & Soc & & \\
\hline$[94]$ & 38 & $9 \mathrm{R}$ & - & 38 & - & $\checkmark$ & - \\
\hline [95] & 44 & $\begin{array}{l}\text { categories-circular model; material } \\
\text { circularity; economic model; } \\
\text { environmental sustainability; social. }\end{array}$ & 6 & 26 & 9 & - & - \\
\hline [17] & 2 & - & & 2 & & - & - \\
\hline [82] & 14 & $\begin{array}{l}\text { categories-production and } \\
\text { consumption; waste management; } \\
\text { secondary raw material; competitiveness } \\
\text { and innovation }\end{array}$ & 2 & 11 & 1 & - & - \\
\hline$[96]$ & 23 & TBL + legislative; technical; business & 5 & 5 & 3 & - & 2 \\
\hline$[97]$ & 1 & - & 0 & 1 & 0 & - & $\checkmark$ \\
\hline [98] & 3 & - & 0 & 3 & 0 & - & - \\
\hline [99] & 1 & - & & 1 & & - & $\checkmark$ \\
\hline [13] & 18 & TBL & 3 & 9 & 6 & - & - \\
\hline [14] & 19 & - & 0 & 19 & 0 & - & - \\
\hline [15] & 31 & $\begin{array}{l}\text { categories-managerial; organizational; } \\
\text { supply chain; informational and } \\
\text { technological; strategy and policy }\end{array}$ & 11 & 11 & 9 & 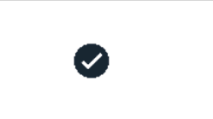 & - \\
\hline
\end{tabular}


Table 5. Cont.

\begin{tabular}{|c|c|c|c|c|c|c|c|}
\hline \multirow{3}{*}{ Ref. } & \multicolumn{7}{|c|}{ Circular Economy Performance Indicators } \\
\hline & \multirow{2}{*}{ Num. } & \multirow{2}{*}{ Categorization } & \multicolumn{3}{|c|}{ TBL Pillars } & \multirow{2}{*}{ Prioritization } & \multirow{2}{*}{ Index } \\
\hline & & & Eco & Env & Soc & & \\
\hline$[100]$ & 4 & - & 0 & 4 & 0 & - & - \\
\hline [79] & 10 & TBL & 4 & 4 & 2 & - & - \\
\hline$[83]$ & 22 & $\begin{array}{l}\text { categories-administrative; waste; } \\
\text { energy; emissions; water }\end{array}$ & 1 & 18 & 2 & - & $\checkmark$ \\
\hline [101] & 3 & $\begin{array}{l}\text { categories—circular product design; } \\
\text { servitised business models; } \\
\text { supply chain management \& reverse } \\
\text { logistics; digital technologies; supply } \\
\text { chain; product range; user; market; } \\
\text { business cost; product structure; failure; } \\
\text { end-of-use; technical; usage; usage cost; } \\
\text { economic impact; environmental impact; } \\
\text { social impact }\end{array}$ & 1 & 2 & 0 & - & - \\
\hline$[102]$ & 8 & categories-eco-efficiency; reuse & 0 & 8 & 0 & - & 2 \\
\hline$[4]$ & $1^{\circ}$ & - & * & * & * & - & 2 \\
\hline$[78]$ & 8 & - & 2 & 6 & 0 & - & - \\
\hline [103] & $10^{\circ}$ & $\begin{array}{c}\text { categories_-production; use end of life; } \\
\text { across life cycle }\end{array}$ & 4 & 6 & 0 & - & - \\
\hline [54] & 12 & - & 2 & 10 & 0 & - & - \\
\hline [104] & 2 & - & 0 & 2 & 0 & - & - \\
\hline$[81]$ & 17 & - & 2 & 12 & 0 & - & 2 \\
\hline [16] & $44^{\circ}$ & categories-micro; macro & & & & - & - \\
\hline [105] & $7^{\circ}$ & categories-material circularity; lifecycle & 0 & 7 & 0 & - & 2 \\
\hline [93] & $63^{\circ}$ & - & & & & - & - \\
\hline [106] & 15 & $\begin{array}{c}\text { categories-lifecycle environmental } \\
\text { impact; lifecycle cost }\end{array}$ & 4 & 11 & 0 & - & - \\
\hline [89] & 2 & - & 0 & 2 & 0 & - & - \\
\hline$[107]$ & 2 & - & 1 & 1 & 0 & 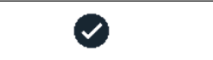 & 2 \\
\hline [75] & 2 & - & 0 & 2 & 0 & - & - \\
\hline [77] & 9 & $\begin{array}{l}\text { categories—technical; economic; } \\
\text { sustainable }\end{array}$ & 3 & 6 & 0 & - & - \\
\hline$[90]$ & 16 & SCOR Processes & 2 & 14 & 0 & - & - \\
\hline [91] & 189 & $\begin{array}{c}\text { categories-environmental; economic; } \\
\text { operational; logistics; } \\
\text { organizational; marketing }\end{array}$ & 12 & 30 & 0 & - & - \\
\hline$[108]$ & 6 & - & 0 & 6 & 0 & - & 2 \\
\hline [109] & 28 & $\begin{array}{l}\text { categories-circular economy; life cycle } \\
\text { resource efficiency; climate energy \& } \\
\text { other; stocks and sufficiency }\end{array}$ & 4 & 24 & 1 & - & - \\
\hline [110] & $5^{\circ}$ & - & & & & - & - \\
\hline
\end{tabular}


Table 5. Cont.

\begin{tabular}{|c|c|c|c|c|c|c|c|}
\hline \multirow{3}{*}{ Ref. } & \multicolumn{7}{|c|}{ Circular Economy Performance Indicators } \\
\hline & \multirow{2}{*}{ Num. } & \multirow{2}{*}{ Categorization } & \multicolumn{3}{|c|}{ TBL Pillars } & \multirow{2}{*}{ Prioritization } & \multirow{2}{*}{ Index } \\
\hline & & & Eco & Env & Soc & & \\
\hline$[111]$ & 1 & - & 0 & 1 & 0 & - & 2 \\
\hline [112] & 17 & TBL + Circularity & 3 & 7 & 7 & - & 2 \\
\hline$[88]$ & 16 & BCS's perspectives & 5 & 4 & 1 & - & - \\
\hline$[53]$ & 15 & $\begin{array}{c}\text { categories } \\
\text { design; manufacturing; } \\
\text { commercialization; in-use; end of use }\end{array}$ & 0 & 15 & 0 & 2 & 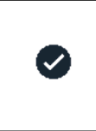 \\
\hline [73] & 1 & - & 1 & 0 & 0 & - & 2 \\
\hline [113] & 2 & - & 0 & 2 & 0 & - & - \\
\hline$[74]$ & 1 & - & 1 & 0 & 0 & - & - \\
\hline$[114]$ & 3 & - & 0 & 3 & 0 & - & 2 \\
\hline [31] & 31 & - & 6 & 17 & 7 & - & - \\
\hline$[76]$ & 1 & - & 0 & 1 & 0 & - & 2 \\
\hline [115] & 1 & - & 0 & 1 & 0 & - & - \\
\hline [116] & 15 & - & 0 & 15 & 0 & - & $\checkmark$ \\
\hline [117] & 31 & $\begin{array}{l}\text { categories—climate change; water; } \\
\text { energy; land use; chemical risks; resource } \\
\text { depletion; material efficiency; } \\
\text { unrecovered materials; } \\
\text { impacts from emissions; end use \& end } \\
\text { of life }\end{array}$ & 0 & 28 & 3 & - & - \\
\hline [118] & 1 & - & & 1 & & - & $\nabla$ \\
\hline [119] & 1 & - & & 1 & & - & 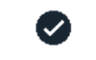 \\
\hline [87] & 13 & $\begin{array}{l}\text { categories-economic; resources; } \\
\text { environment; recycling }\end{array}$ & 3 & 10 & & - & $\vartheta$ \\
\hline [120] & 19 & $\begin{array}{l}\text { categories-energy consumption; } \\
\text { material consumption; waste } \\
\text { disposal and recycle; product and } \\
\text { packing material recovery; green design; } \\
\text { raw material production }\end{array}$ & 0 & 19 & 0 & - & 2 \\
\hline [121] & 34 & $\begin{array}{l}\text { levels—macro; meso } \\
\text { categories—resource output rate; } \\
\text { resource consumption rate; } \\
\text { resource utilization rate; waste disposal }\end{array}$ & 0 & 34 & 0 & - & - \\
\hline [122] & 19 & $\begin{array}{c}\text { categories-resource recycling; pollution } \\
\text { and management; } \\
\text { protection money }\end{array}$ & 6 & 13 & 0 & - & $\theta$ \\
\hline
\end{tabular}


Table 5. Cont.

\begin{tabular}{|c|c|c|c|c|c|c|c|}
\hline \multirow{3}{*}{ Ref. } & \multicolumn{7}{|c|}{ Circular Economy Performance Indicators } \\
\hline & \multirow{2}{*}{ Num. } & \multirow{2}{*}{ Categorization } & \multicolumn{3}{|c|}{ TBL Pillars } & \multirow{2}{*}{ Prioritization } & \multirow{2}{*}{ Index } \\
\hline & & & Eco & Env & Soc & & \\
\hline [123] & 29 & $\begin{array}{l}\text { factors-production flexibility; product } \\
\text { flexibility; delivery flexibility; marketing } \\
\text { flexibility; external coordinated } \\
\text { flexibility; organization flexibility; } \\
\text { manufacturing of flexibility; research and } \\
\text { development flexibility; fiscal policy } \\
\text { system; legal system; public opinion } \\
\text { influence; natural factors; build } \\
\text { mechanisms; incentive mechanisms; trust } \\
\text { mechanisms; interest and risk-sharing } \\
\text { mechanisms; economic factors; technical } \\
\text { factors; inter-enterprise links way }\end{array}$ & 4 & 4 & 0 & - & 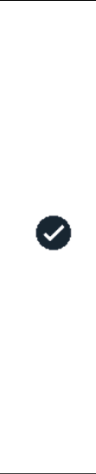 \\
\hline$[124]$ & 30 & positive vs negative & 7 & 14 & 2 & - & 2 \\
\hline$[92]$ & 20 & TBL + element; management & 4 & 4 & 4 & 2 & 2 \\
\hline [125] & 27 & $\begin{array}{c}\text { categories-economic benefits; resources } \\
\text { and energy utilization; } \\
\text { material recycling; pollution control; } \\
\text { production process; development } \\
\text { potential }\end{array}$ & 7 & 20 & 0 & - & 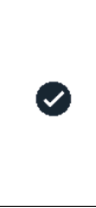 \\
\hline [126] & 11 & $\begin{array}{c}\text { categories-economy; resource used; } \\
\text { resource reused; waste } \\
\text { disposed }\end{array}$ & 3 & 8 & 0 & - & $\checkmark$ \\
\hline [127] & 31 & $\begin{array}{l}\text { categories-financial value; customer } \\
\text { service; costs and benefits; business } \\
\text { process; environmental performance }\end{array}$ & 12 & 6 & 0 & - & $\checkmark$ \\
\hline [128] & 17 & TBL & 3 & 9 & 5 & - & - \\
\hline
\end{tabular}

\subsubsection{Empirical Application: Methods Contexts}

Several studies do not provide an empirical application of the proposed theoretical framework. This prevents an assessment of the proposed frameworks' capability to survive the test of real-case confrontation [153], leading to possible incomplete considerations [34]. The studies providing an empirical application mostly employ the case study methodology $(n=33)$. Few authors adopt the case study for a theory-building perspective, while most of them considered it for theory testing, to understand the usefulness and applicability of their proposed models and framework(s). Looking at the developed case studies, several shortcomings can be noticed. On the one hand, many contributions carried out a very limited number of case studies (one or two), so that a strong linkage with empirical application might be missing [5], and a higher number of case studies would be needed to extend the robustness of validation [4,112]. On the other hand, contributions providing a higher number of case studies focus on a narrow context, such as sector [31], geographical area [73,99], or type of firm, i.e., multi national enterprises [54]. Only a few contributions concentrate on specific sizes, such as SMEs or LEs $([82,83,154]$ and $[13,31,125]$, respectively), while no attention is specifically dedicated to firms with different levels of maturity, resources, competences, or awareness. Additional research should aim to better understand the specific needs of these firms. To identify insights, distinct empirical investigations are precious and essential within the exact context of interest.

The overall evaluation of the reviewed original studies as for the empirical application is reported in Table 6 . 
Table 6. Source Evaluation—original studies (empirical application). The table reports general information of the considered contributions and provides insights on the empirical application in terms of context, methodology, sample employed.

\begin{tabular}{|c|c|c|c|}
\hline \multirow[b]{2}{*}{ Ref. } & \multicolumn{3}{|c|}{ Empirical Application } \\
\hline & $\begin{array}{c}\text { Context of Application } \\
\text { (Sector; Size; Area; Specific Process) }\end{array}$ & Methodology & Sample/Set \\
\hline [94] & - & - & - \\
\hline$[95]$ & manufacturing of tires & case study (theory testing) & 1 \\
\hline$[17]$ & electronic and wood & case study (theory testing) & 2 \\
\hline [82] & Spain, SMEs & case study (theory testing) & 17 \\
\hline [96] & furniture; Sweden & case study (theory testing) & 2 \\
\hline [97] & washing machine & case study (theory testing) & 1 \\
\hline [98] & plastic: Sicily (Italy) & case study (theory testing) & 1 \\
\hline [99] & manufacturing; Sweden & case study (theory testing) & 18 \\
\hline [13] & electronic, textile, plastic; Brazil; LEs & case study (theory building) & 3 \\
\hline [14] & - & - & - \\
\hline [15] & heavy manufacturing; LEs; India & $\begin{array}{c}\text { Best Worst Method; } \\
\text { Decision-Making Trial; Evaluation } \\
\text { Laboratory (theory testing) }\end{array}$ & 1 \\
\hline [100] & - & - & - \\
\hline [79] & engine manufacturing & case study (theory testing) & 1 \\
\hline [83] & food; SMEs; Greece & case study (theory building) & 1 \\
\hline$[101]$ & washing machines; North Europe & case study (theory testing) & 1 \\
\hline [102] & pulp and paper; Spain and Portugal & case study (theory testing) & 2 \\
\hline [4] & manufacturing; SMEs; Mexico & case study (theory testing) & 1 \\
\hline$[78]$ & $\begin{array}{l}\text { tires production; Italy, Switzerland; end } \\
\text { of life }\end{array}$ & case study (theory testing) & 1 \\
\hline [103] & - & - & - \\
\hline$[54]$ & multinational enterprises & case study (theory building) & 13 \\
\hline$[104]$ & plastic; Belgium & case study (theory testing) & 1 \\
\hline [81] & - & - & - \\
\hline [16] & - & - & - \\
\hline$[105]$ & beer packaging; UK and India & case study (theory testing) & 1 \\
\hline [93] & - & - & - \\
\hline [106] & food; UK & case study (theory testing) & 4 \\
\hline [89] & plastics & case study (theory testing) & 1 \\
\hline$[107]$ & food; EU & case study (theory testing) & 1 \\
\hline [75] & mobile phone manufacturer & case study (theory testing) & 1 \\
\hline [77] & - & - & - \\
\hline$[90]$ & - & - & - \\
\hline [91] & - & - & - \\
\hline [108] & biomedical & case study (theory testing) & 1 \\
\hline [109] & - & - & - \\
\hline [110] & energy device manufacturer & case study (theory building) & 1 \\
\hline
\end{tabular}


Table 6. Cont.

\begin{tabular}{|c|c|c|c|}
\hline \multirow[b]{2}{*}{ Ref. } & \multicolumn{3}{|c|}{ Empirical Application } \\
\hline & $\begin{array}{l}\text { Context of Application } \\
\text { (Sector; Size; Area; Specific Process) }\end{array}$ & Methodology & Sample/Set \\
\hline [111] & biomedical & case study (theory testing) & 1 \\
\hline [112] & - & - & - \\
\hline [88] & - & - & - \\
\hline [53] & leather manufacturer & case study (theory testing) & 1 \\
\hline [73] & The Netherlands & case study (theory building) & 40 \\
\hline [113] & plastic (waste); Belgium & case study (theory testing) & 1 \\
\hline [74] & engine manufacturer & examples (theory testing) & 2 \\
\hline [114] & catalytic-converter manufacturer & case study (theory testing) & 1 \\
\hline$[31]$ & biotech and pharmaceutical; LEs & $\begin{array}{l}\text { case study (theory testing); survey } \\
\text { (theory testing) }\end{array}$ & 8 \\
\hline [76] & mobile phone repairer & survey (theory building) & 400 \\
\hline [115] & mobile phones & case study (theory testing) & 1 \\
\hline [116] & vehicles; China; end-of-life & case study (theory testing) & 1 \\
\hline [117] & - & - & - \\
\hline [118] & coal combustion by-products; USA & case study (theory testing) & 1 \\
\hline [119] & - & - & - \\
\hline [87] & - & - & - \\
\hline [120] & - & - & - \\
\hline [121] & - & - & - \\
\hline [122] & - & - & - \\
\hline [123] & coal; China & case study (theory testing) & 1 \\
\hline [124] & chemical; China & case study (theory testing) & 1 \\
\hline [92] & China & case study (theory testing) & 5 \\
\hline [125] & brewery; LEs & case study (theory testing) & 1 \\
\hline [126] & - & - & - \\
\hline [127] & not specified & case study (theory testing) & 1 \\
\hline [128] & metallurgy and energy; China & case study (theory testing) & 2 \\
\hline
\end{tabular}

\section{Discussion}

\subsection{How Can CE Performance Be Measured in Manufacturing Firms?}

Although valuable frameworks are present in the extant literature, some features still need to be properly tackled so as to provide an effective performance-measurement system for the evaluation of $\mathrm{CE}$ performance in manufacturing firms. In the following, specific features are outlined based on the results obtained from the review of the literature; the features are also discussed and confronted against the frameworks currently proposed by the extant literature.

\subsubsection{The Need for an Integrated Performance-Measurement System}

CE should not be a stand-alone concept within manufacturing firms [58,155], and a particularly strong relationship is identified with sustainability $[156,157]$. The literature started considering the three pillars of sustainability for the development of CE-measurement 
systems, but a proper integration is still missing [6,158], particularly concerning the social pillar, as also previously underlined [65].

The environmental pillar is traditionally more developed in the measurement of CE. Almost all the reviewed contributions include environmental indicators (see Figure 5), although the association is not always straightforward. In many cases, the environmental assessment is the only aspect monitored in the frameworks proposed, as in [98,105]. Although contributions typically stress the link between the economic and the environmental pillars in the CE paradigm, the social aspect should not be left behind [66]. The majority of contributions, nonetheless, do not include social indicators, and in general, their inclusion is not explicit, as in [15]. Although specific contributions have begun reconciling CE and sustainability, as in [31] and [112], full integration between the CE and sustainability paradigms needs to be properly addressed.

\subsubsection{The Need for a Holistic Performance-Measurement System}

To properly evaluate $\mathrm{CE}$, performance should be assessed considering not only the single firm (micro level) but also the industrial systems in which it operates (meso level) [86]. Firms should thus be provided with a framework, able to cover the micro level, that also allows insight at the meso level [6]. The literature has nonetheless shown that, so far, manufacturing firms are still focusing their efforts on the adoption of internal practices [4], and also practices involving the industrial system are considered rather complex to implement [41]. Being able to simultaneously measure performance at different $C E$ levels would require the adoption of a holistic system, as the different levels are intimately interconnected and explicable only by their reference in the overall picture. The reviewed contributions do not provide such a perspective, as they focus exclusively on either the product level [96,97], the firm level [15], or on the micro level, in general [103]. Only three contributions consider multiple levels: product and firm [109], micro and macro [16], and macro and meso [121], but a specific holistic integration of the micro and meso levels should be proposed.

\subsubsection{The Need for an Appropriate Theoretical and Empirical Development}

The measurement of performance should allow internal improvement $[159,160]$, communication with external stakeholders [161,162], and benchmarking with peers [163]. In this way, a performance-measurement system should be general enough to be applied in different contexts, such as sector and geographical area, while also allowing a tailored approach to possible distinct needs [18]. Careful considerations need to be made in terms of theoretical development and empirical application. As for the former, a framework should be general and its included indicators should undergo an objective selection and prioritization, based on insights deriving from the different perspectives of IDMs, external stakeholders, academics, and experts [58]. Concerning the last, the capability of the framework to survive empirical tests of its data should be assessed [153]. It would thus be necessary to conduct case studies in heterogeneous contexts [164], effectively corroborating insights from different IDMs within firms operating in the same industrial system. The reviewed studies present shortcomings in this sense. Firstly, several studies are only theoretical and do not provide an empirical analysis [94]. Secondly, even when the proposed frameworks are tested empirically, most consider only one case study $[98,118]$. Many are also focused on a single sector and do not provide indications on how to generalize their results to different firms [83].

\subsection{What Are the Related Implications for SMEs and NAs?}

The reviewed contributions offer little insight for the applications of their developed frameworks in SMEs and NAs. Additionally, as highlighted in the Findings section, the proposed frameworks often clash with the specific needs of SMEs and NAs.

A scalable CE performance-measurement system could be of great help for SMEs and NAs: considering their characteristics, such a framework could represent valid help in 
fostering the enhancement of a firm's overall performance. To be specifically adopted by SMEs and NAs, a system should allow for ease of use and understanding. It should not be excessively complex or time-consuming, given the potentially limited availability of resources and limited level of awareness and competences of SMEs and NAs (see Table 1); rather, a performance-measurement system should be practical and manageable [42], while also providing a quick and comprehensive overview of its main aspects for evaluating CE performance in an integrated and holistic manner. Scalability would thus be of great importance [37,38], as it would allow a system to adapt easily to the changing needs of firms, as their awareness, competences, and maturity grow throughout their $\mathrm{CE}$ transition. Indeed, SMEs and NAs might initially face several difficulties in enhancing their CE performance by adopting practices; at this stage, a framework should be simple and effective at the same time. As firms become more aware and competent about the topic and can better organize their resources towards enhanced CE, their needs, in terms of a framework's features, could change. At this stage, different degrees of depth and breadth of performance measurement should be necessary. From this standing, the performancemeasurement systems should allow for different levels of analysis, with a progressive inclusion of more advanced aspects [42].

Two of the reviewed contributions offer a specific perspective on SMEs, while no indications are provided for NAs. Shortcomings are nonetheless still present: Aravossis et al. [83] focus on SMEs, but their assessment is slightly shifted towards sustainability rather than $\mathrm{CE}$ and does not provide any indication on how to tailor a framework to the needs of specific SMEs. Garza-Reyes et al. [4] provide a measurement toolkit tailored for SMEs, with indications on how to assess the level of circularity of firms; nonetheless, their measurement is based on the number and depth of practices implemented, not on indicators.

\subsection{Towards the Development of an Integrated, Holistic, and Scalable Performance-Measurement System for Manufacturing Firms}

Considering the reviewed literature, a performance-measurement system able to address the above-mentioned features is still missing. To reduce the complexity of the measurement process [18], it is advisable for an effective performance-measurement system to meet all these features.

As for integration, an effective performance-measurement system for CE should provide clear indications regarding the simultaneous coverage of other paradigms within the manufacturing firms, such as sustainability. The indicators included in the system should be assessed in terms of the extent of simultaneous coverage of these two paradigms. Indeed, as the two paradigms are strongly interrelated, it would be sound to understand how the same indicator can provide information in both paradigms, rather than using separate and different indicators for each, as, for example, proposed by [112]. For developing such an integrated system, a great and deep understanding of the interrelations and overlaps between the two paradigms would be, of course, required, and additional value could derive from the simultaneous consideration of the perspectives of multiple IDMs within the same manufacturing firms and their industrial systems [147].

As for the holistic perspective, an effective performance-measurement system for $\mathrm{CE}$ should thus provide coverage of different $\mathrm{CE}$ levels, understanding the interrelations among them. Again, it is advisable to have a single, unique system for measuring performance at different levels, rather than separate ones. This, as well, should issue from a deep understanding of the information provided by the different indicators included in a framework and of the extent of their coverage of different levels of CE application. Once more, it is suggested to consider the perspectives of multiple IDMs [147].

As for scalability, an effective performance-measurement system for CE should be adapted to different firms, specifically SMEs and NAs, according to their characteristics and their evolving needs, in terms of breadth and depth of analysis, while also simultaneously allowing for internal performance measurement and benchmarking activities [18]. Particularly, a scalable framework would allow the presence of different levels of analysis 
and thus sets of indicators. The minimum set would include a limited number of indicators, so as to not distract from the pursuit of a focused strategy $[135,136]$. A minimum set should nonetheless be developed, so as to be able to maximize the content of information for an integrated and holistic evaluation of CE performance [42]. From such an initial set, additional sets should be derived, with an increased number of indicators and an increased content of information provided. The presence of different sets would allow a firm to move among them, according to its characteristics and stage of CE transition [42].

As for the development of such a performance-measurement system, it would be advisable to confront theoretical development with empirical evidence, deriving from its application in manufacturing firms. Particularly, to evaluate the scalability of such a system, longitudinal empirical analyses in SMEs and NAs would be of great relevance.

\section{Concluding Remarks}

The present study critically reviewed the literature proposing frameworks of indicators to measure CE, particularly, investigating how $\mathrm{CE}$ performance can be measured in manufacturing firms, and the related implications for SMEs and NAs.

The analysis shows a growing focus on the development of frameworks, but (i) scarce integration of the proposed frameworks with relevant aspects within manufacturing firms, such as sustainability; (ii) limited empirical validation and application of the developed frameworks; and (iii) limited attention given to the distinct needs of SMEs and NAs. Based on these identified shortcomings, relevant insights for further research are suggested, summarized in the need for an integrated, holistic, and scalable performance-measurement system for measuring $\mathrm{CE}$.

The present study offers contributions from both a theoretical and managerial perspective, following the recommendations of Wickert et al. [165] for literature review. First, 74 literature contributions were analyzed, allowing a comprehensive list of axes for the evaluation of literature reviews and original studies: these axes could prove useful, for scholars and managers alike, as a reference guide to continue the exploration of the topic. Second, a detailed analysis of the previous literature, according to these axes of evaluation, was provided, underlining how each axis should be properly considered, spurring interest in future research. Third, an emerging need for the development of an integrated, holistic, and scalable framework of performance indicators for measuring CE is strongly called for. It would be of great interest to academia, fostering further research, and to practitioners, supporting them in understanding what features to look for in a framework for CE performance measurement. The theoretical development of such research should be then necessarily assessed against empirical applications in manufacturing firms, and particularly in SMEs and NAs. The present study has not considered or evaluated the specific indicators proposed by the reviewed contributions; having understood the main features that an effective performance-measurement system for CE should entail, future research should tackle analysis of indicators, focusing on the identification and selection of the right indicators to be included in integrated, holistic, and scalable frameworks.

The analysis was conducted following the principles of ethical research, quality, and accuracy. Nonetheless, some limitations should be highlighted. First, the study was conducted considering only the Scopus scientific research database; different findings may be obtained from other databases. Second, as the measurement of CE performance is currently a hot topic in the managerial and academic debate-the number of studies on the argument is constantly increasing - and the time frame used could have excluded some relevant recent contributions. Future research should be thus directed to consider the abovementioned limitations, while also investigating the evolution of the research topic.

Author Contributions: Conceptualization, M.N., A.N. and E.C.; methodology, M.N. and A.N.; validation, M.N., A.N. and E.C.; formal analysis, M.N., A.N. and G.M.; writing-original draft preparation, M.N. and A.N.; writing—review and editing, A.N.; visualization, A.N; supervision, A.N.; project administration, A.N. All authors have read and agreed to the published version of the manuscript. 
Funding: This research received no external funding.

Institutional Review Board Statement: Not applicable.

Informed Consent Statement: Not applicable.

Data Availability Statement: Not applicable.

Conflicts of Interest: The authors declare no conflict of interest.

$\begin{array}{ll}\text { Abbreviations } \\ \text { CE } & \text { Circular Economy } \\ \text { IDM } & \text { Industrial Decision Maker } \\ \text { LEs } & \text { Large Enterprises } \\ \text { KPI } & \text { Key Performance Indicator } \\ \text { NAs } & \text { New Adopters } \\ \text { SMEs } & \text { Small and Medium Enterprises }\end{array}$

\section{References}

1. Merli, R.; Preziosi, M.; Acampora, A. How do scholars approach the circular economy? A systematic literature review. J. Clean. Prod. 2018, 178, 703-722. [CrossRef]

2. Kirchherr, J.; Reike, D.; Hekkert, M. Conceptualizing the circular economy: An analysis of 114 definitions. Resour. Conserv. Recycl. 2017, 127, 221-232. [CrossRef]

3. Dey, P.; Malesios, C.; De, D.; Budhwar, P.; Chowdhury, S.; Cheffi, W. Circular Economy to Enhance Sustainability of Small and Medium sized Circular Economy to Enhance Sustainability of Small and Medium sized Enterprises. Bus. Strateg. Environ. 2020, 29, 2145-2169. [CrossRef]

4. Garza-Reyes, J.A.; Salomé Valls, A.; Peter Nadeem, S.; Anosike, A.; Kumar, V. A circularity measurement toolkit for manufacturing SMEs. Int. J. Prod. Res. 2019, 57, 7319-7343. [CrossRef]

5. Mura, M.; Longo, M.; Zanni, S. Circular economy in Italian SMEs: A multi-method study. J. Clean. Prod. 2020, $245,118821$. [CrossRef]

6. Fehrer, J.A.; Wieland, H. A systemic logic for circular business models. J. Bus. Res. 2021, 125, 609-620. [CrossRef]

7. Parida, V.; Burström, T.; Visnjic, I.; Wincent, J. Orchestrating industrial ecosystem in circular economy: A two-stage transformation model for large manufacturing companies. J. Bus. Res. 2019, 101, 715-725. [CrossRef]

8. Patwa, N.; Sivarajah, U.; Seetharaman, A.; Sarkar, S.; Maiti, K.; Hingorani, K. Towards a circular economy: An emerging economies context. J. Bus. Res. 2021, 122, 725-735. [CrossRef]

9. Kumar, V.; Sezersan, I.; Garza-Reyes, J.A.; Gonzalez, E.D.R.S.; AL-Shboul, M.A. Circular economy in the manufacturing sector: Benefits, opportunities and barriers. Manag. Decis. 2019, 57, 1067-1086. [CrossRef]

10. Engida, T.G.; Rao, X.; Berentsen, P.B.M.; Oude Lansink, A.G.J.M. Measuring corporate sustainability performance- the case of European food and beverage companies. J. Clean. Prod. 2018, 195, 734-743. [CrossRef]

11. European Commission. A Circular Economy for Plastics-Insights from Research and Innovation to Inform Policy and Funding Decisions. 2019. Available online: https:/ / op.europa.eu/en/publication-detail/-/publication/33251cf9-3b0b-11e9-8d04-01aa7 5ed71a1/language-en/format-PDF/source-87705298 (accessed on 8 August 2021).

12. Walzberg, J.; Lonca, G.; Hanes, R.J.; Eberle, A.L.; Carpenter, A.; Heath, G.A. Do We Need a New Sustainability Assessment Method for the Circular Economy? A Critical Literature Review. Front. Sustain. 2021, 1, 620047. [CrossRef]

13. Rossi, E.; Bertassini, A.C.; dos Ferreira, C.S.; Neves do Amaral, W.A.; Ometto, A.R. Circular economy indicators for organizations considering sustainability and business models: Plastic, textile and electro-electronic cases. J. Clean. Prod. 2020, $247,119137$. [CrossRef]

14. Sánchez-Ortiz, J.; Rodríguez-Cornejo, V.; Del Río-Sánchez, R.; García-Valderrama, T. Indicators to Measure Efficiency in Circular Economies. Sustainability 2020, 12, 4483. [CrossRef]

15. Yadav, G.; Mangla, S.K.; Bhattacharya, A.; Luthra, S. Exploring indicators of circular economy adoption framework through a hybrid decision support approach. J. Clean. Prod. 2020, 277, 124186. [CrossRef]

16. Moraga, G.; Huysveld, S.; Mathieux, F.; Blengini, G.A.; Alaerts, L.; Van Acker, K.; de Meester, S.; Dewulf, J. Circular economy indicators: What do they measure? Resour. Conserv. Recycl. 2019, 146, 452-461. [CrossRef] [PubMed]

17. Moraga, G.; Huysveld, S.; De Meester, S.; Dewulf, J. Development of circularity indicators based on the in-use occupation of materials. J. Clean. Prod. 2021, 279, 123889. [CrossRef]

18. Neri, A. Industrial Sustainability Performance Measurement System-Challenges for the development. In Methods in Sustainability Science; In, press, Ren, J., Eds.; Elsevier: Amsterdam, The Netherlands, 2021; pp. 87-104, ISBN 9780128239872.

19. Falle, S.; Rauter, R.; Engert, S.; Baumgartner, R.J. Sustainability management with the Sustainability Balanced Scorecard in SMEs: Findings from an Austrian case study. Sustainability 2016, 8, 545. [CrossRef] 
20. Arena, M.; Azzone, G. A process-based operational framework for sustainability reporting in SMEs. J. Small Bus. Enterp. Dev. 2012, 19, 669-686. [CrossRef]

21. Cosenz, F.; Bivona, E. Fostering growth patterns of SMEs through business model innovation. A tailored dynamic business modelling approach. J. Bus. Res. 2021, 130, 658-669. [CrossRef]

22. Johnson, M.P. Sustainability management and small and medium-sized enterprises: Managers' awareness and implementation of innovative tools. Corp. Soc. Responsib. Environ. Manag. 2015, 22, 271-285. [CrossRef]

23. Witjes, S.; Vermeulen, W.J.V.V.; Cramer, J.M. Exploring corporate sustainability integration into business activities. Experiences from 18 small and medium sized enterprises in The Netherlands. J. Clean. Prod. 2017, 153, 528-538. [CrossRef]

24. European Union. Commission Recommendation of 6 May 2003 Concerning the Definition of Micro, Small and Medium-Sized Enterprises. 2003. Available online: http:/ / data.europa.eu/eli/reco/2003/361/oj (accessed on 13 May 2021).

25. Ghenţa, M.; Matei, A. Smes and the circular economy: From policy to difficulties encountered during implementation. Amfiteatru Econ. 2018, 20, 294-309. [CrossRef]

26. Micheli, G.J.L.; Cagno, E.; Neri, A.; Cieri, E. Non-safety costs: A novel methodology for an ex-ante evaluation. Saf. Sci. 2021, 133, 105025. [CrossRef]

27. Albats, E.; Alexander, A.; Mahdad, M.; Miller, K.; Post, G. Stakeholder management in SME open innovation: Interdependences and strategic actions. J. Bus. Res. 2019, 119, 291-301. [CrossRef]

28. Mitchell, S.; O'Dowd, P.; Dimache, A. Manufacturing SMEs doing it for themselves: Developing, testing and piloting an online sustainability and eco-innovation toolkit for SMEs. Int. J. Sustain. Eng. 2020, 13, 159-170. [CrossRef]

29. Feil, A.A.; De Quevedo, D.M.; Schreiber, D. An analysis of the sustainability index of micro- and small-sized furniture industries. Clean Technol. Environ. Policy 2017, 19, 1883-1896. [CrossRef]

30. Katz-Gerro, T.; López Sintas, J. Mapping circular economy activities in the European Union: Patterns of implementation and their correlates in small and medium-sized enterprises. Bus. Strateg. Environ. 2019, 28, 485-496. [CrossRef]

31. Veleva, V.; Bodkin, G.; Todorova, S. The need for better measurement and employee engagement to advance a circular economy: Lessons from Biogen's "zero waste” journey. J. Clean. Prod. 2017, 154, 517-529. [CrossRef]

32. Rovanto, I.K.; Bask, A. Systemic circular business model application at the company, supply chain and society levels-A view into circular economy native and adopter companies. Bus. Strateg. Environ. 2021, 30, 1153-1173. [CrossRef]

33. Gusmerotti, N.M.; Testa, F.; Corsini, F.; Pretner, G.; Iraldo, F. Drivers and approaches to the circular economy in manufacturing firms. J. Clean. Prod. 2019, 230, 314-327. [CrossRef]

34. Saidani, M.; Yannou, B.; Leroy, Y.; Cluzel, F.; Kendall, A. A taxonomy of circular economy indicators. J. Clean. Prod. 2019, 207, 542-559. [CrossRef]

35. Moric, I.; Jovanović, J.Š.; Đoković, R.; Peković, S.; Perović, Đ. The Effect of Phases of the Adoption of the Circular Economy on Firm Performance: Evidence from 28 EU Countries. Sustainability 2020, 12, 2557. [CrossRef]

36. Sehnem, S.; Campos, L.M.S.; Julkovski, D.J.; Cazella, C.F. Circular business models: Level of maturity. Manag. Decis. 2019, 57, 1043-1066. [CrossRef]

37. An, W.; Xu, Y.; Zhang, J. Resource constraints, innovation capability and corporate financial fraud in entrepreneurial firms. Chin. Manag. Stud. 2018, 12, 2-18. [CrossRef]

38. Musso, P.; Schiavo, S. The impact of financial constraints on firm survival and growth. J. Evol. Econ. 2008, 18, 135-149. [CrossRef]

39. Yongtao, W. SMEs in the Circular Economy Development Strategy. Manag. Sci. Eng. 2015, 9, 76-80. [CrossRef]

40. Ormazabal, M.; Prieto-Sandoval, V.; Puga-Leal, R.; Jaca, C. Circular Economy in Spanish SMEs: Challenges and opportunities. J. Clean. Prod. 2018, 185, 157-167. [CrossRef]

41. Masi, D.; Kumar, V.; Garza-Reyes, J.A.; Godsell, J. Towards a more circular economy: Exploring the awareness, practices, and barriers from a focal firm perspective. Prod. Plan. Control 2018, 29, 539-550. [CrossRef]

42. Cagno, E.; Neri, A.; Howard, M.; Brenna, G.; Trianni, A. Industrial sustainability performance measurement systems: A novel framework. J. Clean. Prod. 2019, 230, 1354-1375. [CrossRef]

43. Neri, A.; Cagno, E.; Lepri, M.; Trianni, A. A triple bottom line balanced set of Key Performance Indicators to measure the sustainability performance of industrial supply chains. Sustain. Prod. Consum. 2021, 26, 648-689. [CrossRef]

44. Kristensen, H.S.; Mosgaard, M.A. A review of micro level indicators for a circular economy-Moving away from the three dimensions of sustainability? J. Clean. Prod. 2020, 243, 118531. [CrossRef]

45. Harris, S.; Martin, M.; Diener, D. Circularity for circularity's sake? Scoping review of assessment methods for environmental performance in the circular economy. Sustain. Prod. Consum. 2021, 26, 172-186. [CrossRef]

46. Thomé, A.M.T.; Scavarda, L.F.; Scavarda, A.J. Conducting systematic literature review in operations management. Prod. Plan. Control 2016, 27, 408-420. [CrossRef]

47. Howard, J.; Piacentino, J.; MacMahon, K.; Schulte, P. Using systematic review in occupational safety and health. Am. J. Ind. Med. 2017, 60, 921-929. [CrossRef] [PubMed]

48. Tranfield, D.; Denyer, D. Producing a systematic review. In The Sage Handbook of Organizational Research Methods; SAGE: Thousand Oaks, CA, USA, 2009; pp. 672-688.

49. Denyer, D.; Tranfield, D.; Van Aken, J.E. Developing design propositions through research synthesis. Organ. Stud. 2008, 29, 393-413. [CrossRef] 
50. Palmaccio, M.; Dicuonzo, G.; Belyaeva, Z.S. The internet of things and corporate business models: A systematic literature review. J. Bus. Res. 2021, 131, 610-618. [CrossRef]

51. Roos Lindgreen, E.; Salomone, R.; Reyes, T. A Critical Review of Academic Approaches, Methods and Tools to Assess Circular Economy at the Micro Level. Sustainability 2020, 12, 4973. [CrossRef]

52. Cagno, E.; Neri, A.; Negri, M.; Bassani, C.A.; Lampertico, T. The Role of Digital Technologies in Operationalizing the Circular Economy Transition: A Systematic Literature Review. Appl. Sci. 2021, 11, 3328. [CrossRef]

53. Cayzer, S.; Griffiths, P.; Beghetto, V. Design of indicators for measuring product performance in the circular economy. Int. J. Sustain. Eng. 2017, 10, 289-298. [CrossRef]

54. Howard, M.; Hopkinson, P.; Miemczyk, J. The regenerative supply chain: A framework for developing circular economy indicators. Int. J. Prod. Res. 2019, 57, 7300-7318. [CrossRef]

55. Avellar, S.A.; Thomas, J.; Kleinman, R.; Sama-Miller, E.; Woodruff, S.E.; Coughlin, R.; Westbrook, T.R. External Validity: The Next Step for Systematic Reviews? Eval. Rev. 2017, 41, 283-325. [CrossRef]

56. Xiao, Y.; Watson, M. Guidance on Conducting a Systematic Literature Review. J. Plan. Educ. Res. 2019, 39, 93-112. [CrossRef]

57. Engert, S.; Rauter, R.; Baumgartner, R.J. Exploring the integration of corporate sustainability into strategic management: A literature review. J. Clean. Prod. 2016, 112, 2833-2850. [CrossRef]

58. De Pascale, A.; Arbolino, R.; Szopik-Depczyńska, K.; Limosani, M.; Ioppolo, G. A systematic review for measuring circular economy: The 61 indicators. J. Clean. Prod. 2021, 281, 124942. [CrossRef]

59. Sousa, R.; Voss, C.A. Contingency research in operations management practices. J. Oper. Manag. 2008, 26, 697-713. [CrossRef]

60. Choudhury, R.G. Relationship between contextual factors, business performance, and strategy: A study of manufacturing and service industries in India. Bus. Manag. Rev. 2016, 7, 295-303.

61. Maestrini, V.; Luzzini, D.; Maccarrone, P.; Caniato, F. Supply chain performance measurement systems: A systematic review and research agenda. Int. J. Prod. Econ. 2017, 183, 299-315. [CrossRef]

62. Kravchenko, M.; Pigosso, D.C.; McAloone, T.C. Towards the ex-ante sustainability screening of circular economy initiatives in manufacturing companies: Consolidation of leading sustainability-related performance indicators. J. Clean. Prod. 2019, 241, 118318. [CrossRef]

63. Trianni, A.; Cagno, E.; Neri, A. Modelling barriers to the adoption of industrial sustainability measures. J. Clean. Prod. 2017, 168, 1482-1504. [CrossRef]

64. Tonelli, F.; Evans, S.; Taticchi, P. Industrial sustainability: Challenges, perspectives, actions. Int. J. Bus. Inov. Res. 2013, 7, 143-163. [CrossRef]

65. de Oliveira, C.T.; Dantas, T.E.T.; Soares, S.R. Nano and micro level circular economy indicators: Assisting decision-makers in circularity assessments. Sustain. Prod. Consum. 2021, 26, 455-468. [CrossRef]

66. Padilla-Rivera, A.; Russo-Garrido, S.; Merveille, N. Addressing the social aspects of a circular economy: A systematic literature review. Sustainability 2020, 12, 7912. [CrossRef]

67. Vinante, C.; Sacco, P.; Orzes, G.; Borgianni, Y. Circular economy metrics: Literature review and company-level classification framework. J. Clean. Prod. 2021, 288, 125090. [CrossRef]

68. Corona, B.; Shen, L.; Reike, D.; Rosales Carreón, J.; Worrell, E. Towards sustainable development through the circular economy-A review and critical assessment on current circularity metrics. Resour. Conserv. Recycl. 2019, 151, 104498. [CrossRef]

69. Sassanelli, C.; Rosa, P.; Rocca, R.; Terzi, S. Circular economy performance assessment methods: A systematic literature review. J. Clean. Prod. 2019, 229, 440-453. [CrossRef]

70. Sandin, G.; Peters, G.M. Environmental impact of textile reuse and recycling-A review. J. Clean. Prod. 2018, 184, 353-365. [CrossRef]

71. Su, B.; Heshmati, A.; Geng, Y.; Yu, X. A review of the circular economy in China: Moving from rhetoric to implementation. J. Clean. Prod. 2013, 42, 215-227. [CrossRef]

72. Fitch-Roy, O.; Benson, D.; Monciardini, D. Going around in circles? Conceptual recycling, patching and policy layering in the EU circular economy package. Env. Polit. 2020, 29, 983-1003. [CrossRef]

73. Di Maio, F.; Rem, P.C.; Baldé, K.; Polder, M. Measuring resource efficiency and circular economy: A market value approach. Resour. Conserv. Recycl. 2017, 122, 163-171. [CrossRef]

74. Linder, M.; Sarasini, S.; van Loon, P. A Metric for Quantifying Product-Level Circularity. J. Ind. Ecol. 2017, 21, 545-558. [CrossRef]

75. Figge, F.; Thorpe, A.S.; Givry, P.; Canning, L.; Franklin-Johnson, E. Longevity and Circularity as Indicators of Eco-Efficient Resource Use in the Circular Economy. Ecol. Econ. 2018, 150, 297-306. [CrossRef]

76. Flipsen, B.; Bakker, C.; Van Bohemen, G. Developing a reparability indicator for electronic products. In Proceedings of the 2016 Electronics Goes Green 2016+ (EGG), Berlin, Germany, 6-9 September 2016; pp. 1-9.

77. Grimaud, G.; Perry, N.; Laratte, B. Development of an Evaluation Tool for Engineering Sustainable Recycling Pathways. Procedia CIRP 2018, 69, 781-786. [CrossRef]

78. Gigli, S.; Landi, D.; Germani, M. Cost-benefit analysis of a circular economy project: A study on a recycling system for end-of-life tyres. J. Clean. Prod. 2019, 229, 680-694. [CrossRef]

79. Alamerew, Y.A.; Brissaud, D. Circular economy assessment tool for end of life product recovery strategies. J. Remanuf. 2019, 9, 169-185. [CrossRef] 
80. Ellen MacArthur Foundation. Circularity Indicators: An Approach to Measuring Circularity. 2015. Available online: https://www. ellenmacarthurfoundation.org/assets/downloads/insight/Circularity-Indicators_Project-Overview_May2015.pdf (accessed on 8 August 2021).

81. Koksharov, V.; Starodubets, N.; Ponomareva, M. Assessment of an enterprise circular economy development. WSEAS Trans. Bus. Econ. 2019, 16, 559-567.

82. Rincón-Moreno, J.; Ormazábal, M.; Álvarez, M.J.; Jaca, C. Advancing circular economy performance indicators and their application in Spanish companies. J. Clean. Prod. 2021, 279, 123605. [CrossRef]

83. Aravossis, K.G.; Kapsalis, V.C.; Kyriakopoulos, G.L.; Xouleis, T.G. Development of a holistic assessment framework for industrial organizations. Sustainability 2019, 11, 3946. [CrossRef]

84. The Royal Academy of Engineering. Industrial Systems: Capturing Value through Manufacturing. 2012. Available online: https://www.raeng.org.uk/publications/reports/industrial_systems_capturing_value) (accessed on 1 August 2021).

85. Massaroni, E.; Cozzolino, A.; Wankowicz, E. Sustainability in supply chain management-A literature review. Sinergie 2015, 33, 331-355. [CrossRef]

86. Shibin, K.T.; Gunasekaran, A.; Dubey, R. Explaining sustainable supply chain performance using a total interpretive structural modeling approach. Sustain. Prod. Consum. 2017, 12, 104-118. [CrossRef]

87. Zhang, J.; Wang, N.; Hong, J. Comprehensive evaluation on the development of industry cluster circular economy. Adv. Mater. Res. 2013, 779, 1777-1780. [CrossRef]

88. Butzer, S.; Schötz, S.; Petroschke, M.; Steinhilper, R. Development of a Performance Measurement System for International Reverse Supply Chains. Procedia CIRP 2017, 61, 251-256. [CrossRef]

89. Brown, P.J.; Bajada, C. An economic model of circular supply network dynamics: Toward an understanding of performance measurement in the context of multiple stakeholders. Bus. Strateg. Environ. 2018, 27, 643-655. [CrossRef]

90. Jain, S.; Jain, N.K.; Metri, B. Strategic framework towards measuring a circular supply chain management. Benchmarking 2018, 25, 3238-3252. [CrossRef]

91. Kazancoglu, Y.; Kazancoglu, I.; Sagnak, M. A new holistic conceptual framework for green supply chain management performance assessment based on circular economy. J. Clean. Prod. 2018, 195, 1282-1299. [CrossRef]

92. Li, W. Comprehensive evaluation research on circular economic performance of eco-industrial parks. Energy Procedia 2011, 5, 1682-1688. [CrossRef]

93. Parchomenko, A.; Nelen, D.; Gillabel, J.; Rechberger, H. Measuring the circular economy-A Multiple Correspondence Analysis of 63 metrics. J. Clean. Prod. 2019, 210, 200-216. [CrossRef]

94. Franco, N.G.; Almeida, M.F.L.; Calili, R.F. A strategic measurement framework to monitor and evaluate circularity performance in organizations from a transition perspective. Sustain. Prod. Consum. 2021, 27, 1165-1182. [CrossRef]

95. Vimal, K.E.K.; Kulatunga, A.K.; Ravichandran, M.; Kandasamy, J. Application of multi grade fuzzy approach to compute the circularity index of manufacturing organizations. Procedia CIRP 2021, 98, 476-481. [CrossRef]

96. Alamerew, Y.A.; Kambanou, M.L.; Sakao, T.; Brissaud, D. A multi-criteria evaluation method of product-level circularity strategies. Sustainability 2020, 12, 5129. [CrossRef]

97. Bracquené, E.; Dewulf, W.; Duflou, J.R. Measuring the performance of more circular complex product supply chains. Resour. Conserv. Recycl. 2020, 154, 104608. [CrossRef]

98. Cascone, S.; Ingrao, C.; Valenti, F.; Porto, S.M.C. Energy and environmental assessment of plastic granule production from recycled greenhouse covering films in a circular economy perspective. J. Environ. Manage. 2020, 254, 109796. [CrossRef] [PubMed]

99. Linder, M.; Boyer, R.H.W.; Dahllöf, L.; Vanacore, E.; Hunka, A. Product-level inherent circularity and its relationship to environmental impact. J. Clean. Prod. 2020, 260, 121096. [CrossRef]

100. Akrivos, V.; Haines-Gadd, M.; Mativenga, P.; Charnley, F. Improved metrics for assessment of immortal materials and products. Procedia CIRP 2019, 80, 596-601. [CrossRef]

101. Bressanelli, G.; Perona, M.; Saccani, N. Assessing the impacts of circular economy: A framework and an application to the washing machine industry. Int. J. Manag. Decis. Mak. 2019, 18, 282. [CrossRef]

102. de Abreu Ferreira, I.; de Castro Fraga, M.; Godina, R.; Barreiros, M.S.; Carvalho, H. A proposed index of the implementation and maturity of circular economy practices-the case of the pulp and paper industries of Portugal and Spain. Sustainability 2019, 11, 1722. [CrossRef]

103. Helander, H.; Petit-Boix, A.; Leipold, S.; Bringezu, S. How to monitor environmental pressures of a circular economy: An assessment of indicators. J. Ind. Ecol. 2019, 23, 1278-1291. [CrossRef]

104. Huysveld, S.; Hubo, S.; Ragaert, K.; Dewulf, J. Advancing circular economy benefit indicators and application on open-loop recycling of mixed and contaminated plastic waste fractions. J. Clean. Prod. 2019, 211, 1-13. [CrossRef]

105. Niero, M.; Kalbar, P.P. Coupling material circularity indicators and life cycle based indicators: A proposal to advance the assessment of circular economy strategies at the product level. Resour. Conserv. Recycl. 2019, 140, 305-312. [CrossRef]

106. Slorach, P.C.; Jeswani, H.K.; Cuéllar-Franca, R.; Azapagic, A. Environmental and economic implications of recovering resources from food waste in a circular economy. Sci. Total Environ. 2019, 693, 133516. [CrossRef]

107. Cristóbal, J.; Castellani, V.; Manfredi, S.; Sala, S. Prioritizing and optimizing sustainable measures for food waste prevention and management. Waste Manag. 2018, 72, 3-16. [CrossRef] 
108. Mesa, J.; Esparragoza, I.; Maury, H. Developing a set of sustainability indicators for product families based on the circular economy model. J. Clean. Prod. 2018, 196, 1429-1442. [CrossRef]

109. Pauliuk, S. Critical appraisal of the circular economy standard BS 8001:2017 and a dashboard of quantitative system indicators for its implementation in organizations. Resour. Conserv. Recycl. 2018, 129, 81-92. [CrossRef]

110. Walker, S.; Coleman, N.; Hodgson, P.; Collins, N.; Brimacombe, L. Evaluating the Environmental Dimension of Material Efficiency Strategies Relating to the Circular Economy. Sustainability 2018, 10, 666. [CrossRef]

111. Angioletti, C.M.; Despeisse, M.; Rocca, R. Product Circularity Assessment Methodology Cecilia. IFIP Adv. Inf. Commun. Technol. 2017, 514, 411-418. [CrossRef]

112. Azevedo, S.; Godina, R.; Matias, J. Proposal of a Sustainable Circular Index for Manufacturing Companies. Resources 2017, 6, 63. [CrossRef]

113. Huysman, S.; De Schaepmeester, J.; Ragaert, K.; Dewulf, J.; De Meester, S. Performance indicators for a circular economy: A case study on post-industrial plastic waste. Resour. Conserv. Recycl. 2017, 120, 46-54. [CrossRef]

114. Saidani, M.; Yannou, B.; Leroy, Y.; Cluzel, F. How to Assess Product Performance in the Circular Economy? Proposed Requirements for the Design of a Circularity Measurement Framework. Recycling 2017, 2, 6. [CrossRef]

115. Franklin-Johnson, E.; Figge, F.; Canning, L. Resource duration as a managerial indicator for Circular Economy performance. J. Clean. Prod. 2016, 133, 589-598. [CrossRef]

116. Pan, Y.; Li, H. Sustainability evaluation of end-of-life vehicle recycling based on emergy analysis: A case study of an end-of-life vehicle recycling enterprise in China. J. Clean. Prod. 2016, 131, 219-227. [CrossRef]

117. Rönnlund, I.; Reuter, M.; Horn, S.; Aho, J.; Aho, M.; Päällysaho, M.; Ylimäki, L.; Pursula, T. Eco-efficiency indicator framework implemented in the metallurgical industry: Part 1-A comprehensive view and benchmark. Int. J. Life Cycle Assess. 2016, 21, 1473-1500. [CrossRef]

118. Park, J.Y.; Chertow, M.R. Establishing and testing the "reuse potential" indicator for managing wastes as resources. J. Environ. Manage. 2014, 137, 45-53. [CrossRef]

119. Li, S.L. Study on the model of quantitative evaluation of circular economy development for industry manufacturing based on WIOA. Appl. Mech. Mater. 2013, 345, 384-387. [CrossRef]

120. Zheng, J.; Zheng, C. Research on a Circular Economy Index System Frame of Manufacturing Industrial Chain. In International Asia Conference on Industrial Engineering and Management Innovation (IEMI2012) Proceedings; Qi, E., Shen, J., Dou, R., Eds.; Springer: Berlin/Heidelberg, Germany, 2013; pp. 1389-1399. ISBN 978-3-642-38445-5.

121. Geng, Y.; Fu, J.; Sarkis, J.; Xue, B. Towards a national circular economy indicator system in China: An evaluation and critical analysis. J. Clean. Prod. 2012, 23, 216-224. [CrossRef]

122. Jiang, C.-H.; Jiang, P. Analysis on evaluation index system of enterprise environmental performance under circular economy. In Proceedings of the 2012 International Conference on Management Science \& Engineering 19th Annual Conference Proceedings, Dallas, TX, USA, 20-22 September 2012; pp. 658-663. [CrossRef]

123. Tang, L.H.; Tian, Y.H. The fuzzy comprehensive evaluation of the flexible development of circular economy in enterprise. In Proceedings of the 2012 International Conference on Management Science \& Engineering 19th Annual Conference Proceedings, Dallas, TX, USA, 20-22 September 2012; pp. 408-415. [CrossRef]

124. Zheng, J.; Huang, Y.; Wang, Z. Study on establishment and application of circular economy evaluation index system for the chemical industry. Adv. Mater. Res. 2012, 524-527, 3455-3458. [CrossRef]

125. An, X.H.; Cui, Y.M.; Qi, E.S. Study on eco-efficiency evaluation of manufacturing system based on Circular economy. In Proceedings of the 2010 IEEE 17th International Conference on Industrial Engineering and Engineering Management, Xiamen, China, 29-31 October 2010; pp. 591-593. [CrossRef]

126. Chen, L.J.; Li, J.; Chen, L.K. Evaluating performance of circular economy for manufacturing enterprise based on the theories of EFA and MFA. In Proceedings of the 2010 IEEE 17th International Conference on Industrial Engineering and Engineering Management, Xiamen, China, 29-31 October 2010; pp. 515-519. [CrossRef]

127. Xu, J. Model of cluster green supply chain performance evaluation based on circular economy. In Proceedings of the 2009 Second International Conference on Intelligent Computation Technology and Automation, Changsha, China, 10-11 October 2009; Volume 3, pp. 941-944. [CrossRef]

128. Zheng, J. Structural design and empirical analysis on the circular economy index system for energy-intensive industries. In Proceedings of the 2009 16th International Conference on Industrial Engineering and Engineering Management, Beijing, China, 21-23 October 2009; pp. 2141-2145. [CrossRef]

129. Martín-Peña, M.L.; Díaz-Garrido, E.; Sánchez-López, J.M. Analysis of benefits and difficulties associated with firms' Environmental Management Systems: The case of the Spanish automotive industry. J. Clean. Prod. 2014, 70, 220-230. [CrossRef]

130. Murillo-Luna, J.L.; Garcés-Ayerbe, C.; Rivera-Torres, P. Barriers to the adoption of proactive environmental strategies. J. Clean. Prod. 2011, 19, 1417-1425. [CrossRef]

131. Veleva, V.; Ellenbecker, M. Indicators of sustainable production: Framework and methodology. J. Clean. Prod. 2001, 9, 519-549. [CrossRef]

132. Ahi, P.; Searcy, C. An analysis of metrics used to measure performance in green and sustainable supply chains. J. Clean. Prod. 2015, 86, 360-377. [CrossRef] 
133. Trianni, A.; Cagno, E.; Neri, A.; Howard, M. Measuring industrial sustainability performance: Empirical evidence from Italian and German manufacturing small and medium enterprises. J. Clean. Prod. 2019, 229, 1355-1376. [CrossRef]

134. Garengo, P.; Biazzo, S.; Bititci, U.S. Performance measurement systems in SMEs: A review for a research agenda. Int. J. Manag. Rev. 2005, 7, 25-47. [CrossRef]

135. Epstein, M.J.; Widener, S.K. Identification and use of sustainability performance measures in decision-making. J. Corp. Citizsh. 2010, 40, 43-73. [CrossRef]

136. Medini, K.; Da Cunha, C.; Bernard, A. Tailoring performance evaluation to specific industrial contexts-Application to sustainable mass customisation enterprises. Int. J. Prod. Res. 2015, 53, 2439-2456. [CrossRef]

137. Collins, A.J.; Hester, P.; Ezell, B.; Horst, J. An improvement selection methodology for key performance indicators. Environ. Syst. Decis. 2016, 36, 196-208. [CrossRef]

138. Globerson, S. Issues in developing a performance criteria system for an organization. Int. J. Prod. Res. 1985, 23, 639-646. [CrossRef]

139. Saeed, M.A.; Kersten, W. Sustainability performance assessment framework: A cross-industry multiple case study. Int. J. Sustain Dev. World Ecol. 2020, 27, 496-514. [CrossRef]

140. Nobre, G.C.; Tavares, E. The quest for a circular economy final definition: A scientific perspective. J. Clean. Prod. 2021, $314,127973$. [CrossRef]

141. Padilla-Rivera, A.; do Carmo, B.B.T.; Arcese, G.; Merveille, N. Social circular economy indicators: Selection through fuzzy delphi method. Sustain. Prod. Consum. 2021, 26, 101-110. [CrossRef]

142. Millar, N.; McLaughlin, E.; Börger, T. The Circular Economy: Swings and Roundabouts? Ecol. Econ. 2019, 158, 11-19. [CrossRef]

143. Lieder, M.; Rashid, A. Towards circular economy implementation: A comprehensive review in context of manufacturing industry. J. Clean. Prod. 2016, 115, 36-51. [CrossRef]

144. Thakkar, J.; Kanda, A.; Deshmukh, S.G. Supply chain performance measurement framework for small and medium scale enterprises. Benchmarking 2009, 16, 702-723. [CrossRef]

145. Eckerson, W.W. Performance Management Strategies: How to Create and Deploy Effective Metrics. 2009. Available online: https://tdwi.org/research/2009/01/bpr-1q-performance-management-strategies.aspx (accessed on 13 February 2021).

146. Li, T.; Zhang, H.; Yuan, C.; Liu, Z.; Fan, C. A PCA-based method for construction of composite sustainability indicators. Int. J. Life Cycle Assess. 2012, 17, 593-603. [CrossRef]

147. Cagno, E.; Neri, A.; Trianni, A. Broadening to sustainability the perspective of industrial decision-makers on the energy efficiency measures adoption: Some empirical evidence. Energy Effic. 2018, 11, 1193-1210. [CrossRef]

148. Evans, J.; Bocken, N. Developing a Tool for Manufacturers to Find Opportunity in the Circular Economy. KES Trans. Sustain. Des. Manuf. 2014, 2011, 303-320.

149. Calabrese, A.; Costa, R.; Levialdi, N.; Menichini, T. A fuzzy analytic hierarchy process method to support materiality assessment in sustainability reporting. J. Clean. Prod. 2016, 121, 248-264. [CrossRef]

150. Feng, S.C.; Joung, C.B. A measurement infrastructure for sustainable manufacturing. Int. J. Sustain. Manuf. $2011,2,204-221$. [CrossRef]

151. Gong, M.; Simpson, A.; Koh, L.; Tan, K.H. Inside out: The interrelationships of sustainable performance metrics and its effect on business decision making: Theory and practice. Resour. Conserv. Recycl. 2018, 128, 155-166. [CrossRef]

152. Joung, C.B.; Carrell, J.; Sarkar, P.; Feng, S.C. Categorization of indicators for sustainable manufacturing. Ecol. Indic. 2013, 24, 148-157. [CrossRef]

153. Voss, C.; Tsikriktsis, N.; Frohlich, M. Case research in operations management. Int. J. Oper. Prod. Manag. 2002, 22, 195-219. [CrossRef]

154. Garza-Reyes, J.A.; Villarreal, B.; Kumar, V.; Molina Ruiz, P. Lean and green in the transport and logistics sector-A case study of simultaneous deployment. Prod. Plan. Control 2016, 27, 1221-1232. [CrossRef]

155. Cristoni, N.; Tonelli, M. Perceptions of Firms Participating in a Circular Economy. Eur. J. Sustain. Dev. 2018, 7, 105-118. [CrossRef]

156. Geissdoerfer, M.; Savaget, P.; Bocken, N.M.P.; Hultink, E.J. The Circular Economy-A new sustainability paradigm? J. Clean. Prod. 2017, 143, 757-768. [CrossRef]

157. Panchal, R.; Singh, A.; Diwan, H. Does circular economy performance lead to sustainable development?-A systematic literature review. J. Environ. Manag. 2021, 293, 112811. [CrossRef]

158. Kravchenko, M.; McAloone, T.C.; Pigosso, D.C.A. To what extent do circular economy indicators capture sustainability? Procedia CIRP 2020, 90, 31-36. [CrossRef]

159. Bhanot, N.; Rao, P.V.; Deshmukh, S.G. An integrated sustainability assessment framework: A case of turning process. Clean Technol. Environ. Policy 2016, 18, 1475-1513. [CrossRef]

160. Winroth, M.; Almström, P.; Andersson, C. Sustainable production indicators at factory level. J. Manuf. Technol. Manag. 2016, 27, 842-873. [CrossRef]

161. Fuente, J.A.; García-Sánchez, I.M.; Lozano, M.B. The role of the board of directors in the adoption of GRI guidelines for the disclosure of CSR information. J. Clean. Prod. 2017, 141, 737-750. [CrossRef]

162. Székely, N.; Vom Brockem, J. What can we learn from corporate sustainability reporting? Deriving propositions for research and practice from over 9,500 corporate sustainability reports. PLoS ONE 2017, 12, e0174807. [CrossRef] 
163. Ferrari, A.M.; Volpi, L.; Pini, M.; Cristina, S.; García-Muiña, F.E.; Settembre-Blundo, D. Building a sustainability benchmarking framework of ceramic tiles based on Life Cycle Sustainability Assessment (LCSA). Resources 2019, 8, 11. [CrossRef]

164. Hillebrand, B.; Kok, R.A.W.; Biemans, W.G. Theory-testing using case studies. Ind. Mark. Manag. 2001, 30, 651-657. [CrossRef]

165. Wickert, C.; Post, C.; Doh, J.P.; Prescott, J.E.; Prencipe, A. Management Research that Makes a Difference: Broadening the Meaning of Impact. J. Manag. Stud. 2021, 58, 297-320. [CrossRef] 